\title{
Estimating Beta
}

\author{
Fabian Hollstein and Marcel Prokopczuk*
}

\begin{abstract}
We conduct a comprehensive comparison of market beta estimation techniques. We study the performance of several historical, time-series model, and option-implied estimators for estimating realized market beta. Thereby, we find the hybrid methodology of Buss and Vilkov to consistently outperform all other approaches. In addition, all other approaches, including fully implied and dynamic conditional beta, based on generalized autoregressive conditional heteroskedasticity (GARCH) models, are dominated by a simple beta estimate based on historical (co-)variances and an approach based on the Kalman filter. Our conclusions remain unchanged after performing several robustness checks.
\end{abstract}

\section{Introduction}

Ever since the development of the capital asset pricing model (CAPM) by Sharpe (1964), Lintner (1965), and Mossin (1966) and the arbitrage pricing theory (APT) by Ross (1976), the concept of beta (i.e., the covariation of an asset with the relevant risk factors) has played a crucial role in financial economics. For many applications, such as asset pricing, portfolio choice, or risk management, market beta is the single most important parameter of interest. However, beta factors are not directly observable, and hence they need to be estimated.

The main contribution of this paper is that we are, to the best of our knowledge, the first to provide a comprehensive and thorough empirical study on the performance of a wide range of market beta estimation techniques, including several historical, time-series model, and option-implied estimation approaches. Additionally, we propose a new estimator for beta that corrects option-implied volatilities for the volatility risk premium.

Our main results can be summarized as follows: The approach proposed by Buss and Vilkov (BV) (2012), combining option-implied with historical return information, turns out to outperform all other methods in estimating realized

*Hollstein (corresponding author), hollstein@fmt.uni-hannover.de, Leibniz University Hannover, School of Economics and Management, Hannover 30167, Germany; Prokopczuk, prokopczuk@fmt.uni-hannover.de, Leibniz University Hannover, School of Economics and Management, Hannover 30167, Germany and University of Reading. We thank Hendrik Bessembinder (the editor), Adrian Buss, Chardin Wese Simen, and an anonymous referee and Andrew Patton (a referee) for valuable comments. 
beta (based on daily return data). We determine outperformance in two dimensions: i) informational efficiency and ii) estimation accuracy. The BV approach is shown to be informationally more efficient in encompassing regressions compared with all other approaches, and it yields the lowest out-of-sample estimation errors, employing the root mean squared error (RMSE) criterion. The simple historical benchmark model as well as an approach based on the Kalman filter and a random walk (RW) are shown to work comparatively well, whereas GARCH-based models of dynamic conditional beta and fully option-implied approaches produce serious errors. We further show that the BV approach works so well mainly because, in combining historical and option-implied information, it ensures that the estimates are adjusted to be unbiased in their value-weighted cross-sectional averages.

The most basic approach to estimate beta is to simply estimate covariances and variances from a time series of historical return data. However, this approach faces the problem that beta coefficients exhibit significant time variation (e.g., Blume (1975), Ferson and Harvey (1991), (1993)). To address this concern, several approaches (e.g., GARCH based) have been developed to capture this variability. More recently, it has been suggested that one could incorporate information from the options market, where all information available to investors should be contained in today's prices, thereby overcoming the inertia inherently generated by historical estimates, even when applying a rolling-window approach.

Regarding volatility estimation, which is closely related to beta estimation, numerous studies have been performed. Regarding the performance of the optionimplied versus the historical volatility estimation approach, the results of early studies differ (e.g., Canina and Figlewski (1993), Fleming (1998), and Christensen and Prabhala (1998)). More recently, there seems to be a consensus that implied volatility (IV) estimates are to be favored.

Jiang and Tian (2005) show that model-free IV outperforms at-the-money (ATM) IV and historical volatility. Frijns, Tallau, and Tourani-Rad (2010) and Taylor, Yadav, and Zhang $(2010)^{1}$ show a superior performance of IV compared with different time-series models. Prokopczuk and Wese Simen (2014) show that adjusting for the volatility risk premium improves the performance of IV. Thus, there exists ample evidence on the performance of volatility estimators. ${ }^{2}$

Surprisingly, however, the estimation of beta has received considerably less attention in the literature. Faff, Hillier, and Hillier (2000) find a superior performance of time-series models (especially of those using the Kalman filter) over historical estimates for beta in an in-sample analysis, although they do not present any out-of-sample evidence.

The relative underrepresentation of research studying beta estimation in the extant literature might, to some extent, be caused by the fact that beta requires information on correlations, which is not as easily obtained from options as is

\footnotetext{
${ }^{1}$ For the 1-month horizon estimator.

${ }^{2}$ Other papers on volatility estimation include those by Jorion (1995), Guo (1996), Poon and Granger (2003), Szakmary, Ors, Kim, and Davidson (2003), Martens and Zein (2004), Agnolucci (2009), and Charoenwong, Jenwittayaroje, and Low (2009).
} 
information on volatilities. Only very recently have several authors developed option-implied approaches to estimate beta.

Chang, Christoffersen, Jacobs, and Vainberg (2012) develop such an optionimplied approach and show that it often outperforms the historical beta in a crosssectional analysis. Baule, Korn, and Saßning (2016) compare various different fully implied beta estimators. They obtain the best performance using betas based on implied variances. However, Chang et al. (2012) do not compare their approach for implied betas directly to other existing approaches, and Baule et al. (2016) compare the performance of fully implied estimators only among one another and to the simple historical estimator relying on a small Dow Jones Industrial Average (DJIA) 30 sample.

Buss and Vilkov (2012) propose another implied approach imposing a correction on historical correlations and compare it with historical, hybrid, and the Chang et al. (2012) implied beta estimator. However, they do not examine the performance of time-series models and other fully implied beta estimation techniques. Furthermore, they limit their attention to a comparatively long horizon of 1 year. Very recently, Engle (2014) and Bali, Engle, and Tang (2015) show that dynamic conditional beta does well in a cross-sectional analysis.

The remainder of this paper is organized as follows: Section II describes our data set and methodology, providing an overview of the approaches considered. In Section III we present our empirical results. Section IV checks the robustness of our results, and Section V presents our conclusions.

\section{Data and Methodology}

\section{A. Data}

We base our study on the Standard \& Poor's (S\&P) 500 market index and its constituents for the sample period between Jan. 1, 1996 and Dec. 31, 2012. ${ }^{3}$ Additionally, we perform a robustness analysis on a sample based on the DJIA. ${ }^{4}$ We obtain daily and monthly price data as well as data on dividend payments and shares outstanding from the Center for Research in Security Prices (CRSP) for the period from Jan. 1, 1994 until Dec. 31, 2012. ${ }^{5,6}$ To be able to compute historical and time-series model estimates right from the start of our study period and to perform a portfolio sorting using nonoverlapping data, these data start 2 years before the main sample period.

\footnotetext{
${ }^{3}$ The starting date of our study is thereby determined by the start of the OptionMetrics database in Jan. 1996.

${ }^{4}$ The sample period for the DJIA data set begins on Jan. 1, 1998, because options on the DJIA are traded no earlier than Oct. 1997 at the Chicago Board of Options Exchange (CBOE). We do not start before the beginning of the new year to avoid spurious findings caused by potentially small initial trading volumes in the new market.

${ }^{5}$ The data for monthly estimators, which can be found in the Internet Appendix (available at www.jfqa.org), start on Jan. 1, 1986.

${ }^{6}$ Data on the DJIA are not available through CRSP; therefore, we obtain price data from the Bloomberg database.
} 
Options data are from the IvyDB OptionMetrics Volatility Surface that directly provides implied volatilities for standardized delta levels and maturities. ${ }^{7}$ We use options with approximately 6 months to maturity because we want to obtain 6-month estimates for beta. As a robustness check, we also repeat the analysis with options of approximately 1, 3, and 12 months to maturity. We select out-ofthe-money (OTM) options, namely, puts with deltas larger than -0.5 and calls with deltas smaller than 0.5 . Thereby we obtain options data for 438 stocks in 1996 growing to 493 stocks in 2010 out of the 500 contained in the S\&P 500 at each respective date. On average, options data on 472 stocks are available. Data on the risk-free rate are collected from the IvyDB zero-curve file.

\section{B. Option-Implied Moments}

Several of the beta estimation approaches are based on option-implied moments. Therefore we follow Bakshi, Kapadia, and Madan (BKM) (2003), who make use of the property that any payoff can be spanned using a continuum of OTM puts and calls (Bakshi and Madan (2000)), and Jiang and Tian (2005) to compute model-free option-implied volatility, skewness, and kurtosis. ${ }^{8}$ For that, we first compute ex-dividend stock prices. Second, for any given stock and trading day, we interpolate implied volatilities using a cubic spline across moneyness levels ( $K / S$, strike-to-spot), equally spaced between $0.3 \%$ and $300 \%$, to obtain a grid of 1,000 implied volatilities (Chang et al. (2012)). Implied volatilities outside the range of available strike prices are extrapolated using the value for the smallest (largest) available moneyness level (as in Jiang and Tian (2005) and Chang et al. (2012)). The volatilities are used to compute Black-Scholes (1973) option prices for calls, $C(\cdot)$, if $K / S>1$ and puts, $P(\cdot)$, if $K / S<1$. These are used to obtain the prices of the volatility (QUAD), the CUBIC, and the quartic (QUART) contract (Jiang and Tian (2005)):

(1) $\mathrm{QUAD}=\int_{S}^{\infty} \frac{2\left(1-\ln \left[\frac{K}{S}\right]\right)}{K^{2}} C(\tau, K) d K+\int_{0}^{S} \frac{2\left(1+\ln \left[\frac{S}{K}\right]\right)}{K^{2}} P(\tau, K) d K$,

(2) $\mathrm{CUBIC}=\int_{S}^{\infty} \frac{6 \ln \left[\frac{K}{S}\right]-3\left(\ln \left[\frac{K}{S}\right]\right)^{2}}{K^{2}} C(\tau, K) d K$

$$
+\int_{0}^{S} \frac{6 \ln \left[\frac{S}{K}\right]+3\left(\ln \left[\frac{S}{K}\right]\right)^{2}}{K^{2}} P(\tau, K) d K
$$

\footnotetext{
${ }^{7}$ IvyDB uses a kernel-smoothing algorithm and reports only standardized options "if there exists enough option price data on that date to accurately interpolate the required values." For more details, refer to the IvyDB technical document.

${ }^{8}$ Note that Jiang and Tian (2005) compute implied volatility only. The procedure for skewness, and kurtosis, though, is equivalent.
} 
$\begin{aligned} \text { (3) QUART }= & \int_{S}^{\infty} \frac{12\left(\ln \left[\frac{K}{S}\right]\right)^{2}-4\left(\ln \left[\frac{K}{S}\right]\right)^{3}}{K^{2}} C(\tau, K) d K \\ & +\int_{0}^{S} \frac{12\left(\ln \left[\frac{S}{K}\right]\right)^{2}+4\left(\ln \left[\frac{S}{K}\right]\right)^{3}}{K^{2}} P(\tau, K) d K .\end{aligned}$

The integrals are approximated, following Dennis and Mayhew (2002), using a trapezoidal rule. The option-implied moments can be computed as:

(6) $\mathrm{SKEW}^{\mathrm{Q}}=\frac{e^{r_{t}^{f}(T-t)} \mathrm{CUBIC}-3 \mu^{\mathrm{Q}} e^{r_{t}^{f}(T-t)} \mathrm{QUAD}+2\left(\mu^{\mathrm{Q}}\right)^{3}}{\left[e^{r_{t}^{f}(T-t)} \mathrm{QUAD}-\left(\mu^{\mathrm{Q}}\right)^{2}\right]^{3 / 2}}$,

(7) $\mathrm{KURT}^{\mathrm{Q}}=\frac{e^{r_{t}^{f}(T-t)} \mathrm{QUART}-4 \mu^{\mathrm{Q}} e^{r_{t}^{f}(T-t)} \mathrm{CUBIC}+6\left(\mu^{\mathrm{Q}}\right)^{2} e^{r_{t}^{f}(T-t)} \mathrm{QUAD}-3\left(\mu^{\mathrm{Q}}\right)^{4}}{\left[e^{r_{t}^{f}(T-t)} \mathrm{QUAD}-\left(\mu^{\mathrm{Q}}\right)^{2}\right]^{2}}$,

where $r_{t}^{f}$ denotes the risk-free rate; $T-t$ is the time to maturity of the contract; and $\left(\sigma^{\mathrm{Q}}\right)^{2}, \mathrm{SKEW}^{\mathrm{Q}}$, and $\mathrm{KURT}^{\mathrm{Q}}$ are the option-implied variance, skewness, and kurtosis, respectively. In the following, we use the respective values obtained to compute beta estimates that require option-implied moments.

\section{Beta Estimation}

\section{Realized Beta}

Following Andersen, Bollerslev, Diebold, and Wu (2006), we use daily log returns to compute realized beta $(\mathrm{RB}):^{9}$

$$
\beta_{j, t}^{R}=\frac{\sum_{\tau=1}^{N} r_{j, \tau} r_{M, \tau}}{\sum_{\tau=1}^{N} r_{M, \tau}^{2}},
$$

where $r_{j, \tau}$ and $r_{M, \tau}$ refer to the (excess) return of asset $j$ and the market (excess) return at time $\tau$, respectively. $N$ is the number of observations during the time period under investigation.

Andersen et al. (2006) show that under weak regularity conditions only is this a consistent measure for the true underlying integrated beta. Although Hansen and Lunde (2006) strongly advise using realized volatility when evaluating volatility models, we follow that spirit using ex post realized beta to evaluate all the respective ex ante estimates obtained using the different beta estimation methods.

\section{Historical Beta}

Closely related to the approach just described, we compute historical estimates (HIST) in the usual way, following Fama and MacBeth (FM) (1973) and many others, regressing an asset's (excess) return on the market (excess) return:

$$
\beta_{j, t}=\frac{\operatorname{cov}\left(r_{j, \tau}, r_{M, \tau}\right)}{\operatorname{var}\left(r_{M, \tau}\right)} .
$$

\footnotetext{
${ }^{9}$ We refer to past realized beta as a possible ex ante beta estimation technique as HIST $_{6}$.
} 
We utilize beta estimated using 1 year of daily returns as, for example, in Baker, Bradley, and Wurgler (2010)..$^{10}$

\section{Dynamic Conditional Beta}

We estimate both dynamic conditional beta with GARCH models for the (co-)volatilities and AR-type models that impose certain factor dynamics directly on the beta series. We refer to both types as time-series models.

We consider dynamic conditional beta (Engle (2014), Bali et al. (2015)) using a dynamic conditional correlation (DCC) GARCH model as proposed by Engle (2002) and Cappiello, Engle, and Sheppard (2006), incorporating the empirically well-established leverage effect (by allowing for an asymmetric effect of positive and negative return innovations), as well as an asymmetric reaction of correlations on innovations in variances. ${ }^{11}$ First, univariate volatility models are estimated as proposed by the Glosten, Jagannathan, and Runkle (GJR) (1993) GARCH:

$$
\begin{aligned}
r_{t} & =\mu+a_{t}, \\
a_{t} & \sim N\left(0, \sigma_{t}^{2}\right), \\
h_{t}^{2} & =\omega+\left(\alpha+\gamma \mathrm{I}_{t-1}\left[r_{t-1}<\mu\right]\right) a_{t-1}^{2}+\beta h_{t-1}^{2},
\end{aligned}
$$

where $r_{t}$ is the daily (monthly) asset return, $\mu$ is the mean return, and $a_{t}$ represents the return innovations. $\mathrm{I}_{t-1}\left[r_{t-1}<\mu\right]$ is an indicator function taking the value of 1 if $r_{t-1}$ is lower than $\mu$, and 0 otherwise.

The return innovation series is assumed to be conditionally (on the time $t-1$ information set, $\mathfrak{\Im}_{t-1}$ ) normally distributed with mean 0 and conditional covariance matrix $H_{t}$, which can be decomposed as shown in equation (13). Once the univariate models are estimated, standardized residuals $\epsilon_{i, t}=a_{i, t} / \sqrt{h_{i, t}}$ (with $h_{i, t}$ being the respective variance element in $H_{t}$ ) can be used to estimate the correlation parameters (see Cappiello et al. (2006)):

$$
\begin{aligned}
H_{t}= & D_{t} P_{t} D_{t}, \\
P_{t}= & Q_{t}^{*-1} Q_{t} Q_{t}^{*-1}, \\
Q_{t}= & \left(\bar{P}-A^{\prime} \bar{P} A-B^{\prime} \bar{P} B-G^{\prime} \bar{N} G\right)+A^{\prime} \epsilon_{t-1} \epsilon_{t-1}^{\prime} A \\
& +G^{\prime} n_{t-1} n_{t-1}^{\prime} G+B^{\prime} Q_{t-1} B,
\end{aligned}
$$

where $D_{t}$ is a diagonal matrix containing the standard deviations of the individual assets; $A, B$, and $G$ are $k \times k$ parameter matrices; $n_{t}=I\left[\epsilon_{t}<0\right] \circ \epsilon_{t}$ is a $k \times 1$ indicator function where $\circ$ denotes the Hadamard product (element-wise multiplication); and $Q_{t}^{*}$ is a diagonal matrix containing the square roots of the respective diagonal elements of $Q_{t}$, ensuring that $P_{t}$ is a valid correlation matrix.

We use the model in the bivariate case (i.e., $k=2$ ) for each estimation including an asset-return series and that of the market index at a rolling estimation window of 1 year for daily returns, thereby computing an estimate for the

\footnotetext{
${ }^{10}$ We also test the standard FM (1973) beta computed using 5 years of monthly return data. The results (and results for other monthly beta estimators) can be found in the Internet Appendix (available at www.jfqa.org).

${ }^{11}$ See Black (1976), Christie (1982), and many others.
} 
respective beta in each month of our sample period. ${ }^{12}$ We choose a rolling window instead of an expanding window to allow for structural changes to be incorporated more quickly. The estimation of all time-series models is conducted by maximum likelihood. Using the parameter estimates, we iteratively estimate the covariances and betas for all days until the end of the forecast horizon. The time $t$ estimate is then obtained as the average beta over the forecast horizon.

For robustness, we also test the constant conditional correlation (CCC) model of Bollerslev (1990), neither imposing a dynamic structure on correlations (only on the volatilities) nor an asymmetric effect of return innovations, thereby leaving more degrees of freedom for the estimation process.

\section{Kalman Filter Models}

We also include approaches directly imposing a factor structure on beta and using the Kalman filter (see, e.g., Pagan (1980) and Black, Fraser, and Power (1992)). As underlying dynamics, we consider a random walk (equation (16), RW), a random walk with drift (equation (17), $\mathrm{RW}_{\mathrm{D}}$ ), an $\mathrm{AR}(1)$ (equation (18), AR), and an ARMA(1,1) (equation (19), ARMA) model. In all four cases, the standard CAPM security market line is taken as the measurement equation, and the transition equation describes the chosen model for the dynamic evolution of beta in state-space form:

$$
\begin{aligned}
\beta_{j, \tau}^{\mathrm{RW}} & =\beta_{j, \tau-1}+\epsilon_{j, \tau}, \\
\beta_{j, \tau}^{\mathrm{RW}_{D}} & =\phi_{0}+\beta_{j, \tau-1}+\epsilon_{j, \tau}, \\
\beta_{j, \tau}^{\mathrm{AR}(1)} & =\phi_{1} \beta_{j, \tau-1}+\epsilon_{j, \tau}, \\
\beta_{j, \tau}^{\mathrm{ARMA}(1,1)} & =\phi_{1} \beta_{j, \tau-1}+\epsilon_{j, \tau}+\theta_{1} \epsilon_{j, \tau-1} .
\end{aligned}
$$

We estimate the models analogous to those for dynamic conditional beta, and also use 1 year of daily returns.

A drawback when using the time-series models (both GARCH and Kalman) is that the stability of the model structure has to be assumed. Ghysels (1998) shows that if the factor structure hypothesized is inherently misspecified, the errors made may even increase compared with a static factor model, which might be the major concern regarding this class of estimators. Nevertheless, a superior performance of the time-series model estimators is certainly possible if the true dynamics are approximated sufficiently well.

\section{Option-Implied and Hybrid Betas}

Siegel (1995) points out that an implicit beta could be obtained directly through the use of exchange options, an option to exchange the shares of a firm for the shares of a market index. Unfortunately, however, these exchange options are currently not traded. Thus, one has to rely on some identifying assumption in order to obtain an implicit beta and thereby make use of the inherently forwardlooking information that can be obtained from option prices. It should be taken into consideration, though, that the implied approaches yield estimates (at least

\footnotetext{
${ }^{12}$ For monthly estimators, we use the monthly returns of the past 60 months instead of the past 1 year of daily returns. The results on monthly estimators can be found in the Internet Appendix (available at www.jfqa.org).
} 
partially) under the risk-neutral probability measure, which is likely to differ from the actual physical probability measure if these sources of risk are priced in the market. $^{13}$

We consider several possibilities for option-implied betas, making use of the model-free implied moments discussed previously. These include the hybrid approach of French, Groth, and Kolari (FGK) (1983), which directly combines historical correlations and option-implied volatilities, and that of Buss and Vilkov (2012), who use the property that the implied variance of the market index has to be the same as the implied variance of the value-weighted portfolio of all market constituents (first relation), and combine that with a technical condition for implied correlations to translate from physical $\left(\rho_{i j, t}^{P}\right)$ to risk-neutral correlations $\left(\rho_{i j, t}^{\mathrm{Q}}\right)$, namely, $\rho_{i j, t}^{\mathrm{Q}}=\rho_{i j, t}^{P}-\alpha_{t}\left(1-\rho_{i j, t}^{P}\right) .{ }^{14}$ Combining the two relations and solving for $\alpha_{t}$, implied correlations can be computed. Thus, a beta estimate under the risk-neutral probability measure, $Q$, is obtained by

$$
\beta_{j, t}^{\mathrm{Q}}=\frac{\sigma_{j, t}^{\mathrm{Q}} \sum_{i=1}^{N}\left(\omega_{i, t} \sigma_{i, t}^{\mathrm{Q}} \rho_{j i, t}^{\mathrm{Q}}\right)}{\left(\sigma_{M, t}^{\mathrm{Q}}\right)^{2}},
$$

where $\sigma_{j, t}^{\mathrm{Q}}$ and $\sigma_{M, t}^{\mathrm{Q}}$ denote the implied volatilities obtained in equation (5) for individual stocks and the market index, respectively, ${ }^{15}$ and $\omega_{i, t}$ denotes the weight of the $N$ individual assets in the market index at a certain point in time. One main disadvantage of this approach is the fact that it requires information on all the constituents of the index considered. The estimates are likely to be biased if implied volatilities are not available for all stocks of which the market index consists.

Additionally, we investigate the fully implied approach by Chang et al. (CCJV) (2012) that relies solely on options data. Their estimator is given by

$$
\beta_{j, t}^{\mathrm{CCJV}}=\left(\frac{\operatorname{SKEW}_{j, t}}{\operatorname{SKEW}_{M, t}}\right)^{1 / 3}\left(\frac{\sigma_{j, t}}{\sigma_{M, t}}\right),
$$

using the identifying assumption that the skewness of the idiosyncratic shock equals 0, with $\mathrm{SKEW}_{j, t}$ and $\sigma_{j, t}$ denoting the implied skewness and volatility of individual stocks and with $j=M$ those of the market index, respectively. ${ }^{16}$ As pointed out by Chang et al. (2012), the first part of equation (21) can be regarded as a correlation proxy.

Further, fully implied estimators for beta also rely on certain assumptions on the return moments. A first approach makes use of the restriction made by Skintzi

\footnotetext{
${ }^{13}$ See, for example, Carr and Wu (2009) and Driessen, Maenhout, and Vilkov (2009) for literature on the price of volatility and correlation risk, respectively.

${ }^{14}$ We make sure both that the matrix is a correlation matrix (all correlations not exceeding 1 and the matrix being positive definite) and that it matches with empirical observations, namely, that implied correlations are higher than empirical ones and that the correlation risk premium is higher for lowly correlated stocks. For more details, refer to Buss and Vilkov (2012).

${ }^{15}$ Hereafter, to avoid the notation getting too messy, we suppress the superscript $\mathrm{Q}$ for risk-neutral moments.

${ }^{16}$ Note that equation (21) yields an estimate only if the individual stock's skewness is negative given the usually observed negative skewness of the market. This is an obvious shortcoming, especially for practical purposes.
} 
and Refenes (SR) (2005), who impose the assumption that the return correlation is identical for all stocks in the cross section. This yields the estimator

$$
\beta_{j, t}^{\mathrm{SR}}=\frac{\omega_{j, t} \sigma_{j, t}+\sum_{i \neq j} \omega_{i, t} \rho_{t} \sigma_{j, t} \sigma_{i, t}}{\sigma_{M, t}^{2}} .
$$

Kempf, Korn, and Saßning (2015) propose two further possibilities that are related to the previous approaches. The first approach assumes that the proportion of idiosyncratic variance is equal for all stocks in the cross section (KKS1), resulting in

$$
\beta_{j, t}^{\mathrm{KKS} 1}=\frac{\sigma_{j, t}}{\sum_{i=1}^{N} \omega_{i, t} \sigma_{i, t}} .
$$

Second, they propose a beta estimator imposing the restriction that the proportion of idiosyncratic kurtosis is identical for all stocks in the cross section (KKS2). This yields:

$$
\beta_{j, t}^{\mathrm{KKS} 2}=\frac{\mathrm{KURT}_{\mathrm{US}, j, t}^{1 / 4}}{\sum_{i=1}^{N} \omega_{i, t} \mathrm{KURT}_{\mathrm{US}, i, t}^{1 / 4}},
$$

where $\mathrm{KURT}_{\mathrm{US}, j, t}$ is the unscaled kurtosis as obtained in Section II.B, equation (7). ${ }^{17}$

\section{Risk Premium Adjustment}

The option-implied approaches estimate beta under the risk-neutral probability measure. However, in most situations we are interested in beta under the physical probability measure. We therefore propose a new hybrid estimator for beta that employs forward-looking information from option prices and, at the same time, corrects for volatility risk premia. To obtain this estimator, we follow the procedure in Prokopczuk and Wese Simen (2014) to implement an adjustment for the volatility risk premium. For that, we compute average variance risk premia for a period of just under 2 years: ${ }^{18}$

$$
\mathrm{ARVRP}_{j, t}^{2}=\frac{1}{504-\tau} \sum_{i=t-504}^{t-\tau} \frac{\sigma_{j, i, i+\tau}^{2}}{\mathrm{RV}_{j, i, i+\tau}^{2}},
$$

where $\mathrm{ARVRP}_{j, t}^{2}$ denotes the average relative variance risk premium from $t-504$ to $t-\tau, \sigma_{j, i, i+\tau}^{2}$ is the model-free implied variance of asset $j$ at time $i$ for the period until $i+\tau$ as obtained in equation (5), $\mathrm{RV}_{j, i, i+\tau}^{2}$ is the realized variance over the time period ranging from $i$ to $i+\tau$, and $\tau$ denotes the estimation horizon. To compute the risk premium adjustment we require at least 100 nonmissing

\footnotetext{
${ }^{17}$ Note that in equation (7) the kurtosis is scaled. To obtain the unscaled fourth moment, one has to multiply equation (7) by the squared implied variance. The implied variance is provided in equation (5).

${ }^{18}$ For the risk premium adjustment for evaluation horizons of 3 months or fewer, we compute average variance risk premia for a period of just under 1 year.
} 
observations of both $\sigma_{j, i, i+\tau}^{2}$ and the corresponding $\mathrm{RV}_{j, i, i+\tau}^{2}$. We then obtain the risk-premium-adjusted implied volatility $\mathrm{RMFIV}_{j, t, T}$ for each point in time $t$ as:

$$
\operatorname{RMFIV}_{j, t}=\frac{\sigma_{j, t}}{\operatorname{ARVRP}_{j, t}} .
$$

The risk-premium-adjusted beta (RP_ADJ) is then computed by using the historical correlation $\rho_{j, t}$ and risk-premium-adjusted implied volatilities for individual assets and the market index:

$$
\beta_{j, t}^{\mathrm{RP} \_\mathrm{ADJ}}=\rho_{j, t} \times \frac{\mathrm{RMFIV}_{j, t}}{\operatorname{RMFIV}_{M, t}}
$$

\section{Empirical Results}

\section{A. Summary Statistics and Correlation Analysis}

Panel A of Table 1 reports summary statistics on the different beta estimation techniques. It can be seen that the value-weighted average beta over all stocks in the S\&P $500\left(\mathrm{MEAN}_{\mathrm{vw}}\right)$, a quantity that theoretically has to be equal to 1 , is substantially different from that value in some cases, suggesting that approaches that experience such deviations likely yield biased estimates. Whereas the valueweighted average beta of RW is very close to 1 , those of $R_{D}, A R, A R M A$, and the GARCH DCC and CCC are far off, with values of 1.06, 0.98, 1.04, 0.93, and 1.04 , respectively. Looking at approaches employing information from the options market, we find that the value-weighted averages of especially the hybrid FGK and the fully implied CCJV, as well as SR and RP_ADJ, also are clearly different from 1 , with values of $0.84,1.15,1.04$, and 1.02, respectively. By construction, the quantity is exactly equal to 1 for $\mathrm{BV}, \mathrm{KKS} 1$, and $\mathrm{KKS} 2$, whereas it is relatively close for HIST and $\mathrm{HIST}_{6}$. The time-series model betas RW, RW $\mathrm{D}, \mathrm{ARMA}$, and DCC are shown to vary strongly, with minimum values smaller than -8 and maximum values greater than 16 , potentially inducing large errors for these extreme values. Furthermore, by construction, the fully implied CCJV, SR, KKS1, and KKS2 cannot adopt negative values, casting some doubt on their performance.

Panel B of Table 1 presents the sample correlation coefficients among betas obtained with different estimation techniques on the basis of their estimates for individual assets. We note very high correlations greater than 0.9 among the fully implied estimates (namely, KKS1, KKS2, and SR), FGK, and the risk-premiumadjusted estimates (RP_ADJ), HIST and HIST $_{6}$, as well as among HIST and RP_ADJ. When comparing the remaining estimators, in many cases the correlations are only moderate or quite low. The smallest correlation among the estimates of the remaining approaches is observed between DCC and CCJV, amounting to only 0.39 . This shows that the estimated values vary substantially across the different approaches, providing evidence for the need to study their performance further.

\section{B. Information Content}

A common way to evaluate the performance of ex ante estimates is the Mincer-Zarnowitz (1969) regressions. We therefore regress the 6-month (ex post) 
TABLE 1

Summary Statistics and Sample Correlations

Table 1 provides summary statistics on the different beta estimation techniques in Panel A. All methods utilize (if necessary) daily return data and estimate beta for 6 months. The sample period spans from Jan. 1996 (beginning with estimates for Feb. 1996) until Dec. 2012. No. of Obs. denotes the number of monthly estimates; Mean and MEAN $\mathrm{vw}_{\mathrm{w}}$ are the equaland value-weighted averages of the estimates over the entire sample period, respectively. Std. Dev., Median, Min., and Max. present further summary statistics on the overall standard deviation, median, minimum, and maximum estimate, respectively. Panel B presents the sample correlation coefficients among the different beta estimation techniques on the basis of individual estimates.

Panel A. Summary Statistics

\begin{tabular}{|c|c|c|c|c|c|c|c|c|c|c|c|c|c|c|c|}
\hline & & No & of Obs. & & Mean & & $\underline{\text { MEAN }_{\mathrm{vw}}}$ & & Std. Dev. & & Median & & Min. & & Max. \\
\hline RW & & & 8,179 & & 1.0036 & & 1.0026 & & 0.5720 & & 0.9313 & & -29.075 & & 19.8332 \\
\hline$R W_{D}$ & & & 8,179 & & 1.0713 & & 1.0618 & & 0.7650 & & 0.9807 & & -36.211 & & 24.7961 \\
\hline AR & & & 8,179 & & 0.9662 & & 0.9753 & & 0.7770 & & 0.8349 & & -2.038 & & 20.9860 \\
\hline ARM & & & 8,179 & & 1.0547 & & 1.0369 & & 1.0053 & & 0.8724 & & -8.686 & & 48.6730 \\
\hline DCC & & & 8,176 & & 0.9511 & & 0.9304 & & 0.8068 & & 0.8648 & & -13.997 & & 16.7336 \\
\hline $\mathrm{CCC}$ & & & 8,179 & & 1.0731 & & 1.0430 & & 0.7009 & & 0.9348 & & -0.602 & & 17.9049 \\
\hline HIST & & & 8,243 & & 1.0022 & & 1.0033 & & 0.4680 & & 0.9360 & & -0.667 & & 4.6485 \\
\hline $\mathrm{HIST}_{6}$ & & & 8,630 & & 1.0021 & & 1.0015 & & 0.5036 & & 0.9344 & & -0.981 & & 7.7906 \\
\hline FGK & & & 4,889 & & 0.8473 & & 0.8436 & & 0.3927 & & 0.7998 & & -0.823 & & 5.7060 \\
\hline RP_A & DJ & & 0,190 & & 1.0321 & & 1.0206 & & 0.5208 & & 0.9498 & & -0.855 & & 5.5901 \\
\hline BV & & & 5,043 & & 1.0427 & & 1.0000 & & 0.3756 & & 0.9870 & & -0.464 & & 6.9280 \\
\hline CCJV & & & 9,530 & & 1.2211 & & 1.1505 & & 0.4706 & & 1.1579 & & 0.022 & & 6.2420 \\
\hline SR & & & 5,755 & & 1.1077 & & 1.0391 & & 0.3693 & & 1.0297 & & 0.121 & & 6.2270 \\
\hline KKS1 & & & 5,755 & & 1.1074 & & 1.0000 & & 0.3733 & & 1.0260 & & 0.123 & & 6.2000 \\
\hline KKS2 & & & 5,755 & & 1.1038 & & 1.0000 & & 0.3635 & & 1.0258 & & 0.134 & & 6.3583 \\
\hline Pan & B. Sa & iple C & rrelation & Coeffi & ficients & & & & & & & & & & \\
\hline$\underline{\mathrm{RW}}$ & $\underline{\mathrm{RW}_{\mathrm{D}}}$ & $\underline{\mathrm{AR}}$ & $\underline{\text { ARMA }}$ & $\underline{\mathrm{DCC}}$ & $\underline{\mathrm{CCC}}$ & $\underline{\text { HIST }}$ & $\underline{\mathrm{HIST}_{6}}$ & $\underline{\text { FGK }}$ & $\underline{\text { RP_ADJ }}$ & $\underline{B V}$ & $\underline{\text { CCJV }}$ & $\underline{\mathrm{SR}}$ & $\underline{\mathrm{KKS1}}$ & KKS2 & \\
\hline 1.00 & 0.91 & 0.76 & 0.68 & 0.54 & 0.64 & 0.82 & 0.85 & 0.79 & 0.80 & 0.77 & 0.52 & 0.61 & 0.61 & 0.61 & RW \\
\hline & 1.00 & 0.79 & 0.70 & 0.51 & 0.60 & 0.76 & 0.86 & 0.74 & 0.75 & 0.72 & 0.49 & 0.58 & 0.57 & 0.57 & $\mathrm{RW}_{\mathrm{D}}$ \\
\hline & & 1.00 & 0.67 & 0.44 & 0.52 & 0.68 & 0.76 & 0.66 & 0.68 & 0.64 & 0.43 & 0.49 & 0.48 & 0.48 & AR \\
\hline & & & 1.00 & 0.41 & 0.48 & 0.59 & 0.68 & 0.57 & 0.60 & 0.57 & 0.40 & 0.48 & 0.47 & 0.47 & ARMA \\
\hline & & & & 1.00 & 0.71 & 0.59 & 0.57 & 0.56 & 0.55 & 0.53 & 0.39 & 0.45 & 0.44 & 0.44 & DCC \\
\hline & & & & & 1.00 & 0.71 & 0.68 & 0.66 & 0.66 & 0.64 & 0.48 & 0.56 & 0.56 & 0.56 & $\mathrm{CCC}$ \\
\hline & & & & & & 1.00 & 0.93 & 0.90 & 0.92 & 0.88 & 0.58 & 0.69 & 0.68 & 0.68 & HIST \\
\hline & & & & & & & 1.00 & 0.87 & 0.88 & 0.84 & 0.57 & 0.67 & 0.66 & 0.66 & $\mathrm{HIST}_{6}$ \\
\hline & & & & & & & & 1.00 & 0.95 & 0.89 & 0.67 & 0.71 & 0.70 & 0.70 & FGK \\
\hline & & & & & & & & & 1.00 & 0.90 & 0.64 & 0.74 & 0.73 & 0.73 & RP_ADJ \\
\hline & & & & & & & & & & 1.00 & 0.70 & 0.88 & 0.88 & 0.87 & $\mathrm{BV}^{-}$ \\
\hline & & & & & & & & & & & 1.00 & 0.77 & 0.77 & 0.77 & CCJV \\
\hline & & & & & & & & & & & & 1.00 & 1.00 & 0.99 & SR \\
\hline & & & & & & & & & & & & & 1.00 & 1.00 & KKS1 \\
\hline & & & & & & & & & & & & & & 1.00 & KKS2 \\
\hline
\end{tabular}

realized beta on the different (ex ante) beta estimates in the following way:

$$
\beta_{t, T}^{R}=a+b \zeta_{t, T}+\epsilon_{t}
$$

where $\beta_{t, T}^{R}$ denotes the realized beta in the period ranging from $t$ to $T$, and $\zeta_{t, T}$ stands for one beta estimate in univariate regressions or a vector of several beta estimates in encompassing regressions. With the approach in equation (28) we can test for the informational efficiency and unbiasedness of the respective estimates. ${ }^{19}$ As Hansen and Lunde (2006) show, using logarithmically transformed variables for the regressions, although making the regression procedure less sensitive to outliers (Pagan and Schwert (1990)), often leads to inconsistent rankings of the estimation models if an unbiased but imperfect proxy for the true evaluation variable is used. They further show that level Mincer-Zarnowitz regressions are

\footnotetext{
${ }^{19}$ Although the value-weighted average betas we examine in Section III.A indicate that some approaches are biased on average, with the portfolio approach we employ here, we can test for unbiasedness on a rather individual level.
} 
robust to (mean 0) errors in the proxy. Consequently, we stick to levels instead of $\log$ s to obtain results that are more robust.

Unbiasedness is tested in univariate regressions by performing an $F$-test, imposing the joint hypothesis of $a$ being equal to 0 and $b$ being equal to 1 . For an unbiased model, we should not be able to reject the underlying hypothesis. Informational efficiency can be tested in encompassing regressions by constraining the slope parameters of alternative estimators to 0 , thereby determining if the respective approaches contain information beyond that of a baseline model. If, in encompassing regressions, one estimator is to be more informative, it must have a significant slope estimate, and the explanatory power must rise compared with the restricted model. Additionally, we test the joint hypothesis of one slope parameter being equal to 1 and the second slope parameter being equal to 0 . The underlying hypothesis of this test states that one approach fully subsumes all information contained in the other approach it is tested with.

To conduct our analysis, we follow the approach suggested by Fama and MacBeth (1973). At the end of each month, we form five value-weighted portfolios out of the individual stocks in our sample. We sort the stocks according to their estimate for historical beta (of equation (9)) obtained in an estimation period (sorting period) strictly before the estimation period of the historical beta serving as one beta estimate in an ascending order and compute estimates as well as realizations for beta for each of these portfolios. ${ }^{20}$ This approach ensures that we obtain a certain range in the estimated values and delivers results that are comparable. At the same time, this avoids a bias in our analyses related to a potential errors-in-the-variables problem. To keep the analysis comparable, we can include only those estimates in our sample where all approaches yield an estimate. ${ }^{21}$

To keep the presentation manageable, we select at least one approach from each model family to perform our main analysis. We select historical (HIST), the Kalman filter random walk (RW), DCC GARCH (DCC), the hybrid FGK and $\mathrm{BV}$, the fully implied CCJV and KKS1, and the risk-premium-adjusted (RP_ADJ) approach, and we consider the remaining methods in the robustness analysis in Section IV. In all analyses, we evaluate the approaches using realized beta during the subsequent 6 months. Table 2 presents the regression results for daily estimation approaches. ${ }^{22}$

Panel A of Table 2 presents the results of the univariate regressions for each estimation approach and each of the five portfolios. It can be seen that in most cases the intercept estimate is significantly (at 5\%) (23 $^{23}$ different from 0 , and the

\footnotetext{
${ }^{20}$ For example, using daily data and estimating beta at the end of Jan. 1996, evaluating it in Feb. 1996, the estimation of historical beta uses return data from Feb. 1995 until the end of Jan. 1996. The portfolio sorting is carried out according to the estimate for historical beta using return data between Feb. 1994 and the end of Jan. 1995. If historical return data are not available, the quantity is set to 1. The procedure for monthly analysis is performed accordingly, starting with the first sorting period in Feb. 1986.

${ }^{21}$ The major cause of reduction results from the impossibility of computing the CCJV (2012) beta in some cases, as pointed out in Section II.C, and the general unavailability of sufficient options and return data (see Section III.A).

${ }^{22} \mathrm{~A}$ further analysis on the approaches using monthly return data can be found in the Internet Appendix (available at www.jfqa.org).

${ }^{23}$ Further mentions of (non-)significance will always refer to the $5 \%$ significance level.
} 


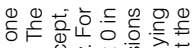
워웡

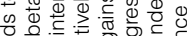
政 फ्र 웅 ว

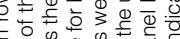

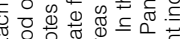

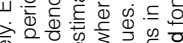

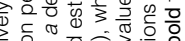

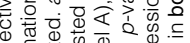

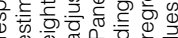

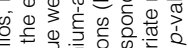

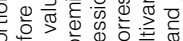

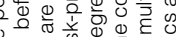

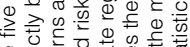

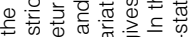

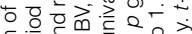

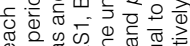

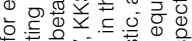
क्.

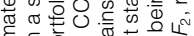

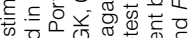
o

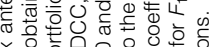
政

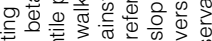

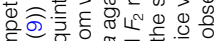

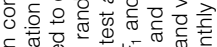
ᄃ

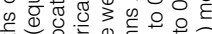

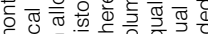

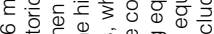

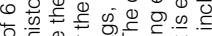

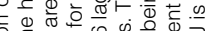
讨

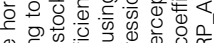

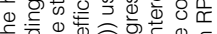

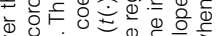
过

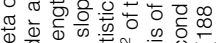

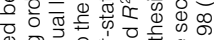

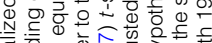

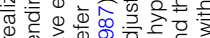

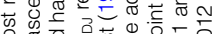

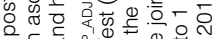

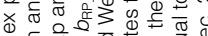

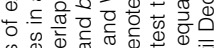

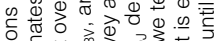

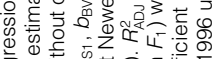

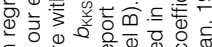
E. 究 कo 等

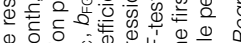

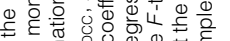
क्.

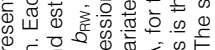

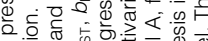

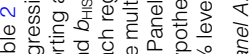

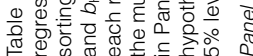

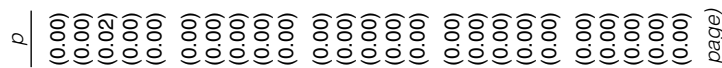

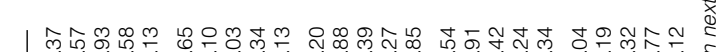

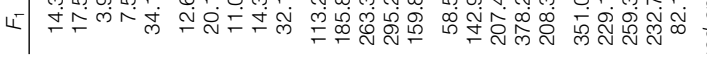

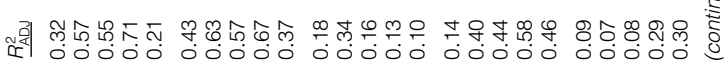
$\widehat{a}$

趐

$\widehat{a}$

高

$\widehat{a}$

产|

永

สู유요 IF产正

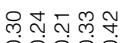

引ํํㅇ

$\widehat{a}$

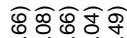

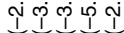

잉

ำ 웅웅 중

$\widehat{Ð}$

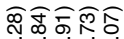

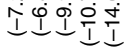

잉

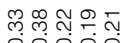

永

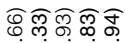
Iบบบ

칭|

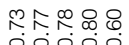

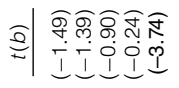

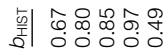

ส

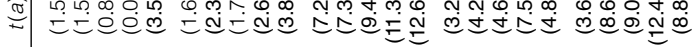

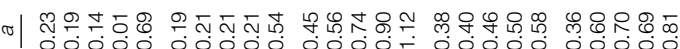

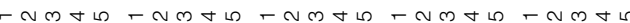

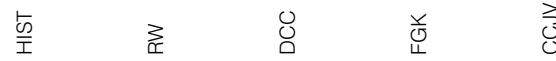




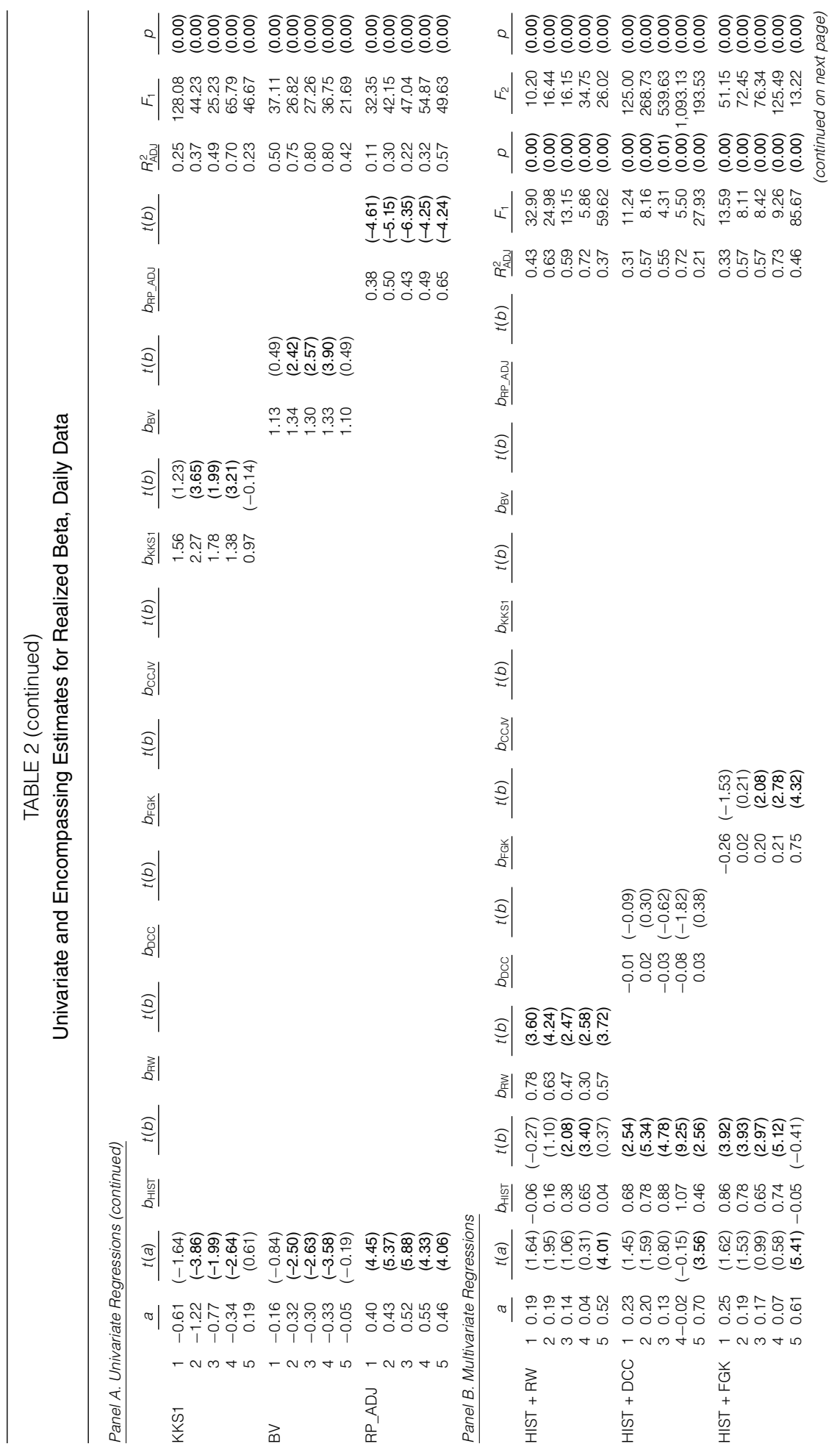




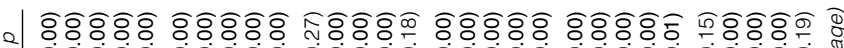

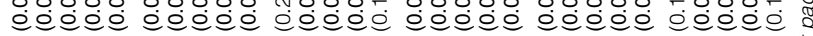

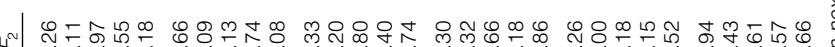

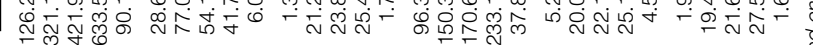

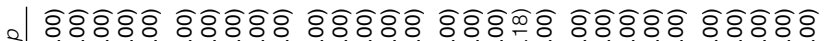

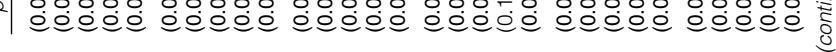

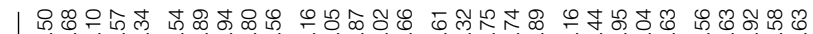
L N

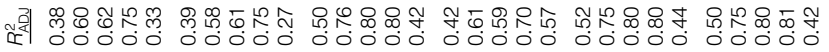

$\stackrel{a}{=}$

率

$\widehat{a}$

高।

$\widehat{a}$

产|

aิ

ल्र लंखुल

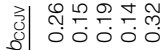

$\widehat{\varrho}$

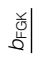

$\widehat{\varrho}$

\&)

$\widehat{\widehat{a}}$

홍|

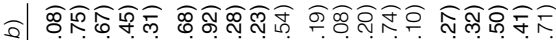

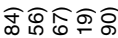
ख்ن

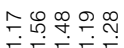

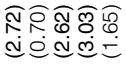

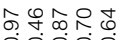
.0.0.0.

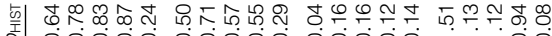

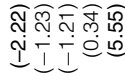
के लेष्ठ OY 100

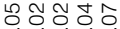
.0.0ं।

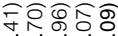
¿일 ลิ 8.80 0.000

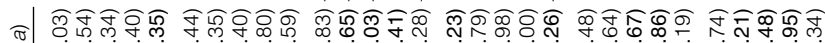
$\approx$ Q ه

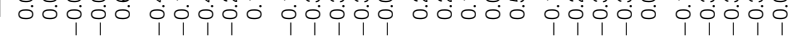

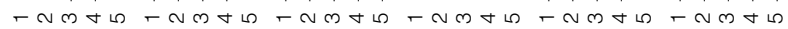
3
3
0
+
$+\frac{5}{I}$
I \begin{tabular}{l}
$\overline{5}$ \\
$\frac{1}{1}$ \\
+ \\
+ \\
\hline \\
\hline
\end{tabular} $\overrightarrow{0}$
+
+
$\frac{00}{I}$ $\overrightarrow{0}$
$\frac{0}{1}$
$\frac{1}{\alpha}$
+
+5
$\frac{5}{1}$

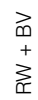




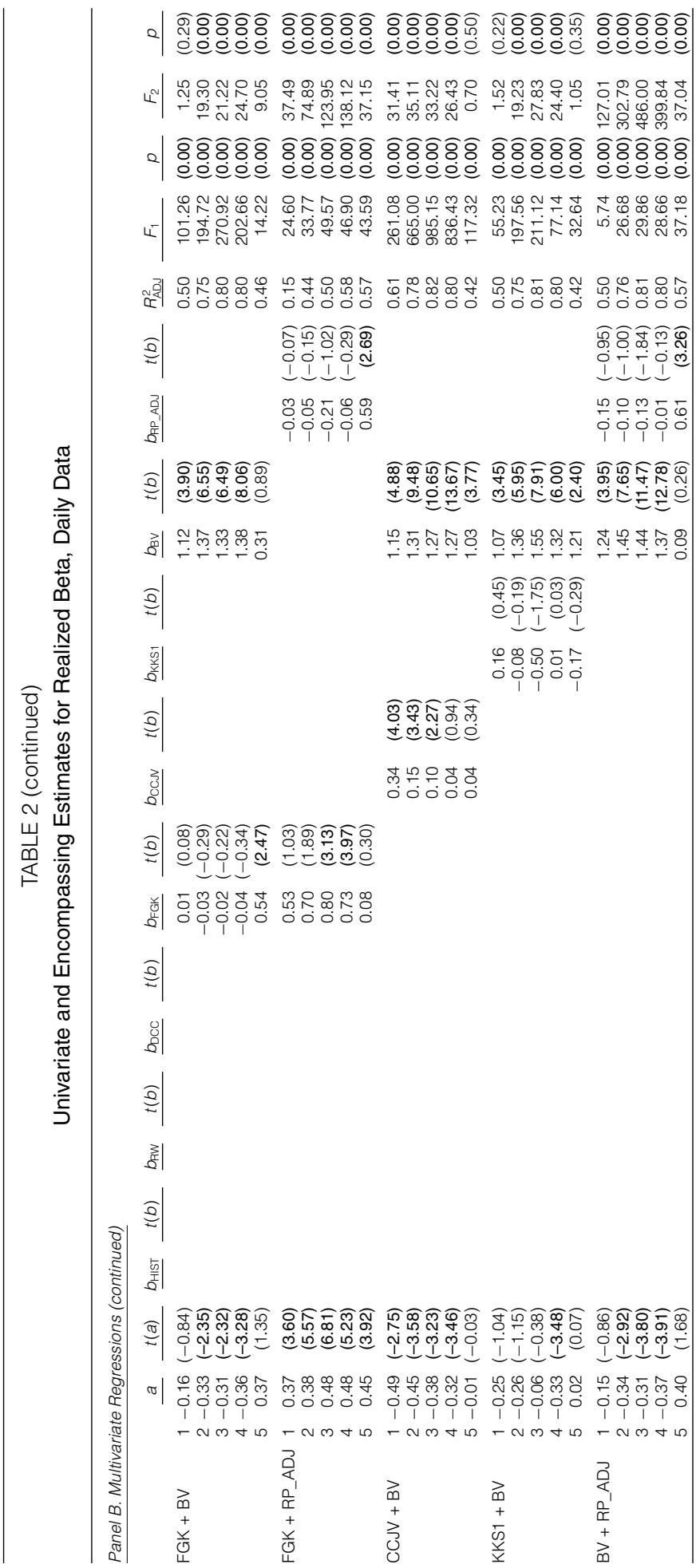


estimate for the slope coefficient is significantly different from $1 .{ }^{24}$ Only the approaches HIST, RW, KKS1, and BV yield nonsignificant values for some portfolios. The joint hypothesis of $a$ being equal to 0 and $b$ being equal to 1 is rejected in any case, suggesting that the approaches yield biased estimates. HIST and RW obtain the lowest values for the $F$-test, but still the null hypothesis of unbiasedness is strongly rejected. For each portfolio except the last, BV yields the highest adjusted $R^{2}$, followed by RW and HIST, indicating that those three approaches exhibit the highest explanatory power. RP_ADJ has the highest explanatory power for portfolio 5. Noteworthy also are the particularly poor performances of DCC and CCJV, yielding very high values for the $F$-statistic and obtaining values for the adjusted $R^{2}$ that are below 0.35 for all portfolios.

Looking at the results of the encompassing regressions in Panel B of Table 2, we find that DCC obtains a rather poor performance, with HIST and BV being informationally more efficient for all portfolios, meaning that in bivariate regressions the coefficients for the latter are significantly different from 0 , whereas those of DCC are not. The BV approach yields a significant slope parameter in every case and is informationally more efficient compared with most other beta estimation approaches. Whenever the slope parameters of other methods competing with BV are significantly different from 0 , they are economically not very large. Only FGK and RP_ADJ yield statistically significant and economically large estimates for one portfolio in a joint encompassing regression together with BV. The explanatory power increases in every case when adding the BV beta to all other models. The hypothesis that one approach subsumes all information contained in another approach (indicated by the tests $F_{1}$ and $F_{2}$ ) is rejected in most cases. There are some cases, though, where the hypothesis that BV subsumes all information contained in, for example, HIST, DCC, or KKS1 cannot be rejected. Combining HIST and the fully implied KKS1, the latter is shown to contain some additional information, making a significant contribution in three out of five cases and, at least slightly, increasing the explanatory power. Comparing FGK and its risk-premium-adjusted counterpart, RP_ADJ, the results are not clear. FGK is favored for two portfolios, and RP_ADJ is favored for one, so it remains unclear if the risk premium adjustment yields an improvement. ${ }^{25}$ In addition, looking at the univariate regressions, further analysis shows that the intercept estimates for FGK and RP_ADJ do not differ significantly. This also conflicts with the possible view that an uniform bias may consistently be removed.

In contrast, comparing our risk-premium-adjusted beta estimator with the BV approach, the latter performs clearly better. Whereas our approach corrects implied volatilities for the well-established variance risk premium and therefore obtains an estimate under the physical probability measure, the BV approach corrects for the risk premium at the level of correlations in the opposite direction and obtains an estimate under the risk-neutral probability measure. Given that realizations under the real-world probability measure are of interest, this is somewhat

\footnotetext{
${ }^{24}$ Note that for univariate regressions, the $t$-statistics of the slope coefficients test the hypothesis of those being equal to 1 and not, as is usually done, equal to 0 . In the multivariate regressions, the $t$-statistics refer to the usual hypothesis that the parameters are equal to 0 .

${ }^{25}$ However, one has to keep in mind that the regression may not be too informative; given the very high correlations between the two, serious problems related to multicollinearity arise.
} 
surprising. A potential explanation is offered by Chang et al. (2012), who show that for certain parameter constellations, the bias caused by the use of risk-neutral moments can be quite small. In other words, in the case of beta, there are biased moments in both the numerator and the denominator, and the two effects may cancel out.

Overall, our results on estimators based on daily return data suggest that the Buss and Vilkov (2012) approach yields the informationally most efficient although not entirely unbiased estimates. Furthermore, the random walk approach, the simple historical estimator, and KKS1 are shown to possess some informational efficiency when compared with the remaining approaches.

\section{Estimation Accuracy}

Turning the focus on out-of-sample estimation accuracy, we employ the loss function most commonly applied in the literature, namely RMSE, to evaluate the performance of the different beta estimation techniques:

$$
\mathrm{RMSE}=\sqrt{\frac{1}{n} \sum_{t=1}^{n}\left(\beta_{t, T}^{R}-\zeta_{t, T}\right)^{2}} .
$$

Here, $n$ is the number of estimation windows, $\beta_{t, T}^{R}$ again denotes the realized beta over a period from $t$ until $T$, and $\zeta_{t, T}$ is the respective beta estimate. Patton (2011) shows that only the mean squared error (MSE) criterion, as opposed to other commonly used loss functions such as mean average error (MAE), mean average percentage error (MAPE), and mean squared percentage error (MSPE), is robust to the presence of (mean 0 ) noise in the evaluation proxy, so we choose this loss function. ${ }^{26}$

Table 3 summarizes the estimation errors using daily return data. We observe that BV yields the smallest average RMSE over the five portfolios (as indicated by italic font), followed by RW and HIST. The fully implied CCJV and the GARCH DCC achieve the worst and second-worst performance, respectively. Adjusting for the volatility risk premium clearly reduces the average estimation error (comparing RP_ADJ to FGK). Overall, both FGK and RP_ADJ, as well as KKS1, can be found in the mid-range regarding the estimation accuracy.

To further examine the results, we analyze whether the differences we observe are statistically significant. The remainder of Table 3 presents the average differences in RMSE in the upper triangular matrix and the respective median differences in the lower triangular matrix. We compute the difference between the errors of the model [name in row] and those of the model [name in column]. The absolute numbers in parentheses indicate the percentage of portfolios for which the difference is statistically significant (e.g., 0.4 indicates that the differences for two out of five portfolios are significant). If the differences are significant for all five portfolios, the figure is printed in bold font. Significance is tested by the modified Diebold-Mariano (Harvey, Leybourne, and Newbold (1997)) and the

\footnotetext{
${ }^{26}$ We present the results on other loss functions, including MAE, MAPE, and MSPE, in the Internet Appendix (available at www.jfqa.org).
} 


\begin{tabular}{|c|c|c|c|c|c|c|c|c|}
\hline \multicolumn{9}{|c|}{$\begin{array}{l}\text { or historical beta without overlap and with equal length). We determine portfolio betas and returns as value-weighted } \\
\text { iverages. The first row reports the average RMSE of the estimation models over the five portfolios. The lowest errors } \\
\text { Imong all approaches are indicated by italic font. The remainder of the table reports the difference in estimation errors. } \\
\text { he upper triangular matrix reports the differences in root mean squared estimation, averaged over the five portfolios. } \\
\text { imilarly, the lower triangular matrix reports the average median difference of estimation errors. We compute the differ- } \\
\text { ance between the errors of the model [name in row] and those of the model [name in column]. The absolute numbers in } \\
\text { arentheses indicate the percentage of portfolios for which the difference is significant (e.g., } 0.4 \text { indicates that the differ- } \\
\text { nces for two out of five portfolios are statistically significant). If the differences are significant for all five portfolios, the } \\
\text { gure is printed in bold font. Significance is tested by the modified Diebold-Mariano and the Wilcoxon signed-rank tests } \\
\text { or the upper and lower triangular matrices, respectively. The sign indicates the direction of the significant differences. }\end{array}$} \\
\hline & HISI & RVV & DUC & FGK & Couv & KKSI & BV & $\underline{\mathrm{KP}_{-}}$ \\
\hline vg. & 0.1381 & 0.1301 & 0.2676 & 0.2203 & 0.2783 & 0.1704 & 0.1164 & 0.171 \\
\hline HIST & & $\begin{array}{l}0.0079 \\
(0.0)\end{array}$ & $\begin{array}{l}-0.1295 \\
(-1.0)\end{array}$ & $\begin{array}{l}-0.0822 \\
(-0.8)\end{array}$ & $\begin{array}{l}-0.1402 \\
(-0.8)\end{array}$ & $\begin{array}{l}-0.0323 \\
(-0.4)\end{array}$ & $\begin{array}{l}0.0217 \\
(0.2)\end{array}$ & $\begin{array}{l}-0.0337 \\
(-0.6)\end{array}$ \\
\hline RW & $\begin{array}{l}0.0002 \\
(-0.4)\end{array}$ & & $\begin{array}{l}-0.1374 \\
(-1.0)\end{array}$ & $\begin{array}{l}-0.0901 \\
(-1.0)\end{array}$ & $\begin{array}{l}-0.1482 \\
(-0.8)\end{array}$ & $\begin{array}{l}-0.0403 \\
(-0.2)\end{array}$ & $\begin{array}{l}0.0138 \\
(0.2)\end{array}$ & $\begin{array}{l}-0.0416 \\
(-0.6)\end{array}$ \\
\hline DCC & $\begin{array}{l}0.0639 \\
(1.0)\end{array}$ & $\begin{array}{l}0.0637 \\
(1.0)\end{array}$ & & $\begin{array}{l}0.0473 \\
(0.0)\end{array}$ & $\begin{array}{l}-0.0108 \\
(0.0)\end{array}$ & $\begin{array}{l}0.0972 \\
(0.6)\end{array}$ & $\begin{array}{l}0.1512 \\
(1.0)\end{array}$ & $\begin{array}{l}0.0958 \\
(0.8)\end{array}$ \\
\hline FGK & $\begin{array}{l}0.1001 \\
(1.0)\end{array}$ & $\begin{array}{l}0.0999 \\
(1.0)\end{array}$ & $\begin{array}{l}0.0362 \\
(0.2)\end{array}$ & & $\begin{array}{l}-0.0581 \\
(-0.6)\end{array}$ & $\begin{array}{l}0.0499 \\
(0.6)\end{array}$ & $\begin{array}{l}0.1039 \\
(1.0)\end{array}$ & $\begin{array}{l}0.0485 \\
(0.2)\end{array}$ \\
\hline CCJV & $\begin{array}{l}0.1143 \\
(1.0)\end{array}$ & $\begin{array}{l}0.1141 \\
(1.0)\end{array}$ & $\begin{array}{l}0.0504 \\
(0.6)\end{array}$ & $\begin{array}{l}0.0142 \\
(0.4)\end{array}$ & & $\begin{array}{l}0.1079 \\
(0.8)\end{array}$ & $\begin{array}{l}0.1620 \\
(1.0)\end{array}$ & $\begin{array}{l}0.1066 \\
(1.0)\end{array}$ \\
\hline KKS1 & $\begin{array}{l}0.0113 \\
(0.4)\end{array}$ & $\begin{array}{l}0.0110 \\
(0.6)\end{array}$ & $\begin{array}{l}-0.0526 \\
(-0.8)\end{array}$ & $\begin{array}{l}-0.0888 \\
(-0.8)\end{array}$ & $\begin{array}{l}-0.1031 \\
(-1.0)\end{array}$ & & $\begin{array}{l}0.0541 \\
(0.8)\end{array}$ & $\begin{array}{l}-0.0013 \\
(-0.2)\end{array}$ \\
\hline BV & $\begin{array}{l}-0.0111 \\
(-0.6)\end{array}$ & $\begin{array}{l}-0.0113 \\
(-0.6)\end{array}$ & $\begin{array}{l}-0.0750 \\
(-1.0)\end{array}$ & $\begin{array}{l}-0.1112 \\
(-1.0)\end{array}$ & $\begin{array}{l}-0.1254 \\
(-1.0)\end{array}$ & $\begin{array}{l}-0.0224 \\
(-1.0)\end{array}$ & & $\begin{array}{l}-0.055 \\
(-0.6)\end{array}$ \\
\hline P_ADJ & $\begin{array}{l}0.0256 \\
(0.8) \\
\end{array}$ & $\begin{array}{l}0.0254 \\
(0.8) \\
\end{array}$ & $\begin{array}{l}-0.0383 \\
(-1.0) \\
\end{array}$ & $\begin{array}{l}-0.0745 \\
(-1.0) \\
\end{array}$ & $\begin{array}{l}-0.0888 \\
(-1.0) \\
\end{array}$ & $\begin{array}{l}0.0143 \\
(0.2) \\
\end{array}$ & $\begin{array}{l}0.0367 \\
(1.0) \\
\end{array}$ & \\
\hline
\end{tabular}

Wilcoxon signed-rank tests for the upper and lower triangular matrix, respectively. The sign indicates the direction of the significant differences.

We find that BV always obtains lower average root mean and median squared errors than the other methods. These differences are statistically significant for all portfolios compared with DCC, FGK, and CCJV, and at least three portfolios compared with KKS1 and RP_ADJ, whereas when comparing with HIST and RW, the RMSE of BV is significantly lower for one portfolio, and the root median SE is significantly lower for three portfolios. HIST and RW yield significantly lower estimation errors than all other methods, except BV and KKS1, for at least three out of the five portfolios, and than KKS1 for at least one portfolio. Overall, the evidence indicates that the BV approach obtains the best out-of-sample accuracy, followed by RW and HIST.

\section{Robustness}

\section{A. More Portfolios}

We test whether the results obtained so far are robust to building more portfolios. Thus, we build 10, 25, and 50 portfolios, and in the limit we also consider the case of individual stocks. Table 4 reports the results, which are quite similar to our previous findings. We observe that the average errors in general increase with the number of portfolios. Independently of the number of portfolios, BV always obtains the lowest average RMSE, yielding the lowest error for a minimum of $60 \%$ when building portfolios. In the case of estimates for individual stocks, BV 
TABLE 4

\section{Estimation Errors: More Portfolios}

\begin{tabular}{|c|c|c|c|c|c|c|c|c|}
\hline & HIST & RW & DCC & FGK & CCJV & KKS1 & BV & RP_ADJ \\
\hline $\begin{array}{l}5 \text { Portfolios } \\
\text { Avg. RMSE }\end{array}$ & $\begin{array}{l}0.1381 \\
(0.00)\end{array}$ & $\begin{array}{l}0.1301 \\
(0.20)\end{array}$ & $\begin{array}{l}0.2676 \\
(0.00)\end{array}$ & $\begin{array}{l}0.2203 \\
(0.00)\end{array}$ & $\begin{array}{l}0.2783 \\
(0.00)\end{array}$ & $\begin{array}{l}0.1704 \\
(0.00)\end{array}$ & $\begin{array}{l}0.1164 \\
(0.60)\end{array}$ & $\begin{array}{l}0.1718 \\
(0.20)\end{array}$ \\
\hline $\begin{array}{l}10 \text { Portfolios } \\
\text { Avg. RMSE }\end{array}$ & $\begin{array}{l}0.1518 \\
(0.00)\end{array}$ & $\begin{array}{l}0.1474 \\
(0.20)\end{array}$ & $\begin{array}{l}0.2868 \\
(0.00)\end{array}$ & $\begin{array}{l}0.2273 \\
(0.00)\end{array}$ & $\begin{array}{l}0.2901 \\
(0.00)\end{array}$ & $\begin{array}{l}0.1854 \\
(0.00)\end{array}$ & $\begin{array}{l}0.1304 \\
(0.80)\end{array}$ & $\begin{array}{l}0.1837 \\
(0.00)\end{array}$ \\
\hline $\begin{array}{l}25 \text { Portfolios } \\
\text { Avg. RMSE }\end{array}$ & $\begin{array}{l}0.1735 \\
(0.00)\end{array}$ & $\begin{array}{l}0.1787 \\
(0.12)\end{array}$ & $\begin{array}{l}0.3260 \\
(0.00)\end{array}$ & $\begin{array}{l}0.2397 \\
(0.00)\end{array}$ & $\begin{array}{l}0.3099 \\
(0.00)\end{array}$ & $\begin{array}{l}0.2075 \\
(0.00)\end{array}$ & $\begin{array}{l}0.1540 \\
(0.84)\end{array}$ & $\begin{array}{c}0.1998 \\
(0.04)\end{array}$ \\
\hline $\begin{array}{l}50 \text { Portfolios } \\
\text { Avg. RMSE }\end{array}$ & $\begin{array}{l}0.1975 \\
(0.10)\end{array}$ & $\begin{array}{l}0.2131 \\
(0.02)\end{array}$ & $\begin{array}{l}0.3683 \\
(0.00)\end{array}$ & $\begin{array}{l}0.2558 \\
(0.00)\end{array}$ & $\begin{array}{l}0.3323 \\
(0.00)\end{array}$ & $\begin{array}{l}0.2340 \\
(0.00)\end{array}$ & $\begin{array}{l}0.1808 \\
(0.80)\end{array}$ & $\begin{array}{l}0.2198 \\
(0.08)\end{array}$ \\
\hline $\begin{array}{l}\text { Individual Assets } \\
\text { Avg. RMSE }\end{array}$ & $\begin{array}{c}0.5374 \\
(0.09)\end{array}$ & $\begin{array}{l}0.5866 \\
(0.12)\end{array}$ & $\begin{array}{l}0.8309 \\
(0.13)\end{array}$ & $\begin{array}{l}0.5592 \\
(0.17)\end{array}$ & $\begin{array}{l}0.6616 \\
(0.15)\end{array}$ & $\begin{array}{l}0.5826 \\
(0.13)\end{array}$ & $\begin{array}{l}0.5363 \\
(0.08)\end{array}$ & $\begin{array}{c}0.5379 \\
(0.11)\end{array}$ \\
\hline
\end{tabular}

also obtains the lowest average RMSE, although not much can be stated because each approach has its share where it yields the lowest errors, indicating that all approaches work well for some stocks. Overall, the BV, HIST, and RW approaches also perform best when increasing the number of portfolios.

\section{B. Different Horizons}

To further examine the robustness of our results, we perform the evaluation using different time horizons, namely 1,3, and 12 months. We estimate the values for option-implied methods using options with approximately $1(3,12)$ month(s) to maturity and adjust the horizon for time-series models to the respective time frame, evaluating all the methods using realized beta over the subsequent 1,3 , and 12 months, respectively.

Panel A of Table 5 reports the estimation errors of our main methods and their significance for the 1-month evaluation period. We find that using this evaluation horizon yields the same result, with BV, HIST, and RW being the approaches with the best out-of-sample estimation accuracy. BV obtains the lowest average RMSE. Comparing the mean and median differences of the estimation errors, only in relation to KKS1, HIST and RW do not yield a significantly lower error, at least for $80 \%$ of the portfolios, whereas BV always does. For some portfolios, BV yields significantly lower median errors compared with HIST and RW. The results for 3 and 12 months in Panels B and C are qualitatively equal. BV always obtains the lowest average RMSE, with significantly lower errors in many cases compared with the other approaches.

Summing up, when changing the evaluation period to 1,3 , or 12 months, BV, $\mathrm{RW}$, and, to a slightly lesser extent, HIST are still the best approaches. 


\section{Further Models for Implied Beta}

We examine further possible beta estimators utilizing information from option prices. Looking at Panel A of Table 6, we find KKS2, based on implied kurtosis, to obtain quite similar results as KKS1, based on implied volatilities. Both yield a little higher estimation errors than SR, which is also based on implied volatilities, whereas all three yield substantially lower estimation errors com-

\section{TABLE 5}

Estimation Errors: Different Horizons, Daily Data

Table 5 reports the out-of-sample estimation errors of competing estimators, using daily return data, for realized beta over horizons of 1 (Panel A), 3 (Panel B), and 12 (Panel C) months for each portfolio. We build five quintile portfolios into which the stocks are allocated in an ascending order according to their historical beta in the sorting period (taking place directly before the estimation period for historical beta without overlap and with equal length). We determine portfolio betas and returns as value-weighted averages. In each panel, the first row reports the average RMSE of the estimation models over the five portfolios. The lowest errors among all approaches are indicated by italic font. The remainder of the panels report the difference in estimation errors. The upper triangular matrices report the differences in root mean squared estimation errors, averaged over the five portfolios. Similarly, the lower triangular matrices report the average root median difference of estimation errors. We compute the difference between the errors of the model [name in row] and those of the model [name in column]. The absolute numbers in parentheses indicate the percentage of portfolios for which the difference is significant (e.g., 0.4 indicates that the differences for two out of five portfolios are statistically significant). If the differences are significant for all five portfolios, the figure is printed in bold font. Significance is tested by the modified Diebold-Mariano and the Wilcoxon signed-rank tests for the upper and lower triangular matrices, respectively. The sign indicates the direction of the significant differences.

Panel A. 1 Month

\begin{tabular}{|c|c|c|c|c|c|c|c|c|}
\hline & HIST & RW & DCC & FGK & CCJV & KKS1 & BV & RP_ADJ \\
\hline Avg. & 0.1637 & 0.1515 & 0.2231 & 0.2193 & 0.4285 & 0.2051 & 0.1483 & 0.1977 \\
\hline HIST & & $\begin{array}{l}0.0122 \\
(0.0)\end{array}$ & $\begin{array}{l}-0.0594 \\
(-0.8)\end{array}$ & $\begin{array}{l}-0.0556 \\
(-0.8)\end{array}$ & $\begin{array}{l}-0.2648 \\
(-0.8)\end{array}$ & $\begin{array}{l}-0.0414 \\
(-0.2)\end{array}$ & $\begin{array}{l}0.0153 \\
(0.0)\end{array}$ & $\begin{array}{l}-0.0340 \\
(-0.8)\end{array}$ \\
\hline RW & $\begin{array}{l}-0.0022 \\
(-0.2)\end{array}$ & & $\begin{array}{l}-0.0717 \\
(-1.0)\end{array}$ & $\begin{array}{l}-0.0678 \\
(-1.0)\end{array}$ & $\begin{array}{l}-0.2770 \\
(-1.0)\end{array}$ & $\begin{array}{l}-0.0536 \\
(-0.4)\end{array}$ & $\begin{array}{l}0.0031 \\
(0.0)\end{array}$ & $\begin{array}{l}-0.0462 \\
(-0.8)\end{array}$ \\
\hline DCC & $\begin{array}{l}0.0375 \\
(1.0)\end{array}$ & $\begin{array}{l}0.0397 \\
(1.0)\end{array}$ & & $\begin{array}{l}0.0038 \\
(0.0)\end{array}$ & $\begin{array}{l}-0.2053 \\
(-0.8)\end{array}$ & $\begin{array}{l}0.0181 \\
(0.4)\end{array}$ & $\begin{array}{l}0.0748 \\
(1.0)\end{array}$ & $\begin{array}{l}0.0254 \\
(0.0)\end{array}$ \\
\hline FGK & $\begin{array}{l}0.0525 \\
(1.0)\end{array}$ & $\begin{array}{l}0.0547 \\
(1.0)\end{array}$ & $\begin{array}{l}0.0150 \\
(0.0)\end{array}$ & & $\begin{array}{l}-0.2092 \\
(-0.8)\end{array}$ & $\begin{array}{l}0.0142 \\
(0.4)\end{array}$ & $\begin{array}{l}0.0709 \\
(1.0)\end{array}$ & $\begin{array}{l}0.0216 \\
(0.0)\end{array}$ \\
\hline CCJV & $\begin{array}{l}0.1550 \\
(1.0)\end{array}$ & $\begin{array}{l}0.1572 \\
(1.0)\end{array}$ & $\begin{array}{l}0.1175 \\
(1.0)\end{array}$ & $\begin{array}{l}0.1025 \\
(0.8)\end{array}$ & & $\begin{array}{l}0.2234 \\
(0.8)\end{array}$ & $\begin{array}{l}0.2801 \\
(1.0)\end{array}$ & $\begin{array}{l}0.2308 \\
(0.8)\end{array}$ \\
\hline KKS1 & $\begin{array}{l}0.0189 \\
(0.4)\end{array}$ & $\begin{array}{l}0.0211 \\
(0.6)\end{array}$ & $\begin{array}{l}-0.0186 \\
(-0.4)\end{array}$ & $\begin{array}{l}-0.0336 \\
(-0.4)\end{array}$ & $\begin{array}{l}-0.1361 \\
(-1.0)\end{array}$ & & $\begin{array}{l}0.0567 \\
(0.6)\end{array}$ & $\begin{array}{l}0.0074 \\
(0.0)\end{array}$ \\
\hline BV & $\begin{array}{l}-0.0041 \\
(-0.4)\end{array}$ & $\begin{array}{l}-0.0020 \\
(-0.2)\end{array}$ & $\begin{array}{l}-0.0417 \\
(-1.0)\end{array}$ & $\begin{array}{l}-0.0567 \\
(-1.0)\end{array}$ & $\begin{array}{l}-0.1592 \\
(-1.0)\end{array}$ & $\begin{array}{l}-0.0231 \\
(-1.0)\end{array}$ & & $\begin{array}{l}-0.0493 \\
(-0.8)\end{array}$ \\
\hline RP_ADJ & $\begin{array}{l}0.0340 \\
(0.8)\end{array}$ & $\begin{array}{l}0.0362 \\
(0.8)\end{array}$ & $\begin{array}{l}-0.0035 \\
(0.0)\end{array}$ & $\begin{array}{l}-0.0185 \\
(-0.6)\end{array}$ & $\begin{array}{l}-0.1210 \\
(-1.0)\end{array}$ & $\begin{array}{l}0.0151 \\
(0.4)\end{array}$ & $\begin{array}{l}0.0382 \\
(0.8)\end{array}$ & \\
\hline
\end{tabular}

Panel B. 3 Months

\begin{tabular}{|c|c|c|c|}
\hline & HIST & RW & DCC \\
\hline Avg. & 0.1380 & 0.1281 & 0.2259 \\
\hline HIST & & $\begin{array}{l}0.0100 \\
(0.0)\end{array}$ & $\begin{array}{l}-0.0879 \\
(-1.0)\end{array}$ \\
\hline RW & $\begin{array}{l}-0.0031 \\
(-0.4)\end{array}$ & & $\begin{array}{l}-0.0979 \\
(-1.0)\end{array}$ \\
\hline DCC & $\begin{array}{l}0.0494 \\
(1.0)\end{array}$ & $\begin{array}{l}0.0525 \\
(1.0)\end{array}$ & \\
\hline FGK & $\begin{array}{l}0.0784 \\
(1.0)\end{array}$ & $\begin{array}{l}0.0815 \\
(1.0)\end{array}$ & $\begin{array}{l}0.0289 \\
(0.2)\end{array}$ \\
\hline CCJV & $\begin{array}{l}0.1313 \\
(1.0)\end{array}$ & $\begin{array}{l}0.1344 \\
(1.0)\end{array}$ & $\begin{array}{l}0.0818 \\
(0.8)\end{array}$ \\
\hline KKS1 & $\begin{array}{l}0.0151 \\
(0.6)\end{array}$ & $\begin{array}{l}0.0182 \\
(0.6)\end{array}$ & $\begin{array}{l}-0.0343 \\
(-0.6)\end{array}$ \\
\hline BV & $\begin{array}{l}-0.0087 \\
(-0.6)\end{array}$ & $\begin{array}{l}-0.0056 \\
(-0.2)\end{array}$ & $\begin{array}{l}-0.0581 \\
(-1.0)\end{array}$ \\
\hline RP_ADJ & $\begin{array}{l}0.0305 \\
(0.8)\end{array}$ & $\begin{array}{l}0.0336 \\
(1.0)\end{array}$ & $\begin{array}{l}-0.0189 \\
(-0.6)\end{array}$ \\
\hline
\end{tabular}

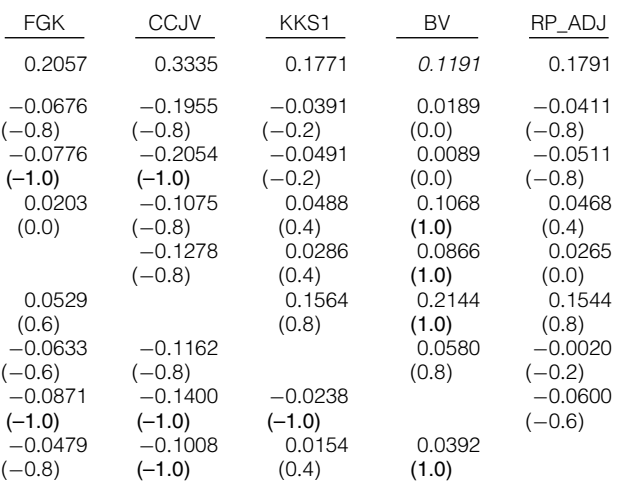


TABLE 5 (continued)

Estimation Errors: Different Horizons, Daily Data

\begin{tabular}{|c|c|c|c|c|c|c|c|c|}
\hline \multicolumn{9}{|c|}{ Panel C. 12 Months } \\
\hline & HIST & RW & DCC & FGK & CCJV & KKS1 & BV & RP_ADJ \\
\hline Avg. & 0.1488 & 0.1423 & 0.3374 & 0.2307 & 0.2674 & 0.1677 & 0.1227 & 0.1895 \\
\hline HIST & & $\begin{array}{l}0.0065 \\
(0.0)\end{array}$ & $\begin{array}{l}-0.1886 \\
(-1.0)\end{array}$ & $\begin{array}{l}-0.0820 \\
(-0.8)\end{array}$ & $\begin{array}{l}-0.1187 \\
(-0.8)\end{array}$ & $\begin{array}{c}-0.0190 \\
(0.0)\end{array}$ & $\begin{array}{l}0.0261 \\
(0.2)\end{array}$ & $\begin{array}{l}-0.0407 \\
(-0.4)\end{array}$ \\
\hline RW & $\begin{array}{c}-0.0019 \\
(0.0)\end{array}$ & & $\begin{array}{l}-0.1951 \\
(-1.0)\end{array}$ & $\begin{array}{l}-0.0884 \\
(-1.0)\end{array}$ & $\begin{array}{l}-0.1251 \\
(-1.0)\end{array}$ & $\begin{array}{l}-0.0254 \\
(-0.2)\end{array}$ & $\begin{array}{l}0.0196 \\
(0.2)\end{array}$ & $\begin{array}{l}-0.0471 \\
(-0.6)\end{array}$ \\
\hline DCC & $\begin{array}{l}0.0714 \\
(1.0)\end{array}$ & $\begin{array}{l}0.0734 \\
(1.0)\end{array}$ & & $\begin{array}{l}0.1067 \\
(0.0)\end{array}$ & $\begin{array}{l}0.0700 \\
(0.2)\end{array}$ & $\begin{array}{l}0.1697 \\
(0.8)\end{array}$ & $\begin{array}{l}0.2147 \\
(1.0)\end{array}$ & $\begin{array}{l}0.1479 \\
(1.0)\end{array}$ \\
\hline FGK & $\begin{array}{l}0.1003 \\
(1.0)\end{array}$ & $\begin{array}{l}0.1023 \\
(1.0)\end{array}$ & $\begin{array}{l}0.0289 \\
(-0.2)\end{array}$ & & $\begin{array}{l}-0.0367 \\
(-0.2)\end{array}$ & $\begin{array}{l}0.0630 \\
(0.8)\end{array}$ & $\begin{array}{l}0.1080 \\
(1.0)\end{array}$ & $\begin{array}{l}0.0413 \\
(0.0)\end{array}$ \\
\hline CCJV & $\begin{array}{l}0.1188 \\
(1.0)\end{array}$ & $\begin{array}{l}0.1208 \\
(1.0)\end{array}$ & $\begin{array}{l}0.0474 \\
(0.2)\end{array}$ & $\begin{array}{l}0.0185 \\
(0.0)\end{array}$ & & $\begin{array}{l}0.0997 \\
(0.8)\end{array}$ & $\begin{array}{l}0.1447 \\
(1.0)\end{array}$ & $\begin{array}{l}0.0780 \\
(0.8)\end{array}$ \\
\hline KKS1 & $\begin{array}{l}0.0054 \\
(0.4)\end{array}$ & $\begin{array}{l}0.0073 \\
(0.4)\end{array}$ & $\begin{array}{l}-0.0660 \\
(-0.8)\end{array}$ & $\begin{array}{l}-0.0950 \\
(-0.8)\end{array}$ & $\begin{array}{l}-0.1135 \\
(-1.0)\end{array}$ & & $\begin{array}{l}0.0450 \\
(0.8)\end{array}$ & $\begin{array}{l}-0.0217 \\
(-0.2)\end{array}$ \\
\hline BV & $\begin{array}{l}-0.0163 \\
(-0.6)\end{array}$ & $\begin{array}{l}-0.0144 \\
(-0.6)\end{array}$ & $\begin{array}{l}-0.0877 \\
(-1.0)\end{array}$ & $\begin{array}{l}-0.1167 \\
(-1.0)\end{array}$ & $\begin{array}{l}-0.1352 \\
(-1.0)\end{array}$ & $\begin{array}{l}-0.0217 \\
(-1.0)\end{array}$ & & $\begin{array}{l}-0.0667 \\
(-0.4)\end{array}$ \\
\hline RP_ADJ & $\begin{array}{l}0.0214 \\
(0.8)\end{array}$ & $\begin{array}{l}0.0234 \\
(1.0)\end{array}$ & $\begin{array}{l}-0.0500 \\
(-1.0)\end{array}$ & $\begin{array}{l}-0.0789 \\
(-1.0)\end{array}$ & $\begin{array}{l}-0.0974 \\
(-1.0)\end{array}$ & $\begin{array}{l}0.0161 \\
(0.4)\end{array}$ & $\begin{array}{l}0.0378 \\
(0.6)\end{array}$ & \\
\hline
\end{tabular}

TABLE 6

Estimation Errors:

6-Month Horizon, Daily Data (Further Implied and DJIA)

Table 6 reports the out-of-sample estimation errors of competing estimators, using daily return data, for realized beta over the horizon of 6 months for each portfolio. We build five (Panel A) and two (Panel B) portfolios into which the stocks are allocated in an ascending order according to their historical beta in the sorting period (taking place directly before the estimation period for historical beta without overlap and with equal length). We determine portfolio betas and returns as value-weighted averages. In each panel, the first row reports the average RMSE of the estimation models over the five (two) portfolios. The lowest errors among all approaches are indicated by italic font. The remainder of the panels report the difference in estimation errors. The upper triangular matrices report the differences in root mean squared estimation errors, averaged over the five (two) portfolios. Similarly, the lower triangular matrices report the average root median difference of estimation errors. We compute the difference between the errors of the model [name in row] and those of the model [name in column]. The absolute numbers in parentheses indicate the percentage of portfolios for which the difference is significant (e.g., 0.4 indicates that the differences for two out of five portfolios are statistically significant). If the differences are significant for all portfolios, the figure is printed in bold font. Significance is tested by the modified Diebold-Mariano and the Wilcoxon signed-rank tests for the upper and lower triangular matrices, respectively. The sign indicates the direction of the significant differences.

Panel A. Further Implied Estimators

\begin{tabular}{|c|c|c|c|c|c|c|c|c|c|}
\hline & HIST & RW & CCJV & $\mathrm{SR}$ & KKS1 & KKS2 & FGK & RP_ADJ & BV \\
\hline Avg. & 0.1381 & 0.1301 & 0.2783 & 0.1674 & 0.1704 & 0.1720 & 0.2203 & 0.1718 & 0.1164 \\
\hline HIST & & $\begin{array}{l}0.0079 \\
(0.0)\end{array}$ & $\begin{array}{l}-0.1402 \\
(-0.8)\end{array}$ & $\begin{array}{l}-0.0293 \\
(-0.2)\end{array}$ & $\begin{array}{l}-0.0323 \\
(-0.4)\end{array}$ & $\begin{array}{l}-0.0339 \\
(-0.4)\end{array}$ & $\begin{array}{l}-0.0822 \\
(-0.8)\end{array}$ & $\begin{array}{l}-0.0337 \\
(-0.6)\end{array}$ & $\begin{array}{l}0.0217 \\
(0.2)\end{array}$ \\
\hline RW & $\begin{array}{l}0.0002 \\
(-0.4)\end{array}$ & & $\begin{array}{l}-0.1482 \\
(-0.8)\end{array}$ & $\begin{array}{l}-0.0372 \\
(-0.2)\end{array}$ & $\begin{array}{l}-0.0403 \\
(-0.2)\end{array}$ & $\begin{array}{l}-0.0419 \\
(-0.2)\end{array}$ & $\begin{array}{l}-0.0901 \\
(-1.0)\end{array}$ & $\begin{array}{l}-0.0416 \\
(-0.6)\end{array}$ & $\begin{array}{l}0.0138 \\
(0.2)\end{array}$ \\
\hline CCJV & $\begin{array}{l}0.1143 \\
(1.0)\end{array}$ & $\begin{array}{l}0.1141 \\
(1.0)\end{array}$ & & $\begin{array}{l}0.1110 \\
(0.8)\end{array}$ & $\begin{array}{l}0.1079 \\
(0.8)\end{array}$ & $\begin{array}{l}0.1063 \\
(0.8)\end{array}$ & $\begin{array}{l}0.0581 \\
(0.6)\end{array}$ & $\begin{array}{l}0.1066 \\
(1.0)\end{array}$ & $\begin{array}{l}0.1620 \\
(1.0)\end{array}$ \\
\hline SR & $\begin{array}{l}0.0153 \\
(0.6)\end{array}$ & $\begin{array}{l}0.0150 \\
(0.4)\end{array}$ & $\begin{array}{l}-0.0991 \\
(-1.0)\end{array}$ & & $\begin{array}{l}-0.0030 \\
(0.4)\end{array}$ & $\begin{array}{l}-0.0046 \\
(0.4)\end{array}$ & $\begin{array}{l}-0.0529 \\
(-0.6)\end{array}$ & $\begin{array}{l}-0.0044 \\
(0.0)\end{array}$ & $\begin{array}{l}0.0510 \\
(0.8)\end{array}$ \\
\hline KKS1 & $\begin{array}{l}0.0113 \\
(0.4)\end{array}$ & $\begin{array}{l}0.0110 \\
(0.6)\end{array}$ & $\begin{array}{l}-0.1031 \\
(-1.0)\end{array}$ & $\begin{array}{l}-0.0040 \\
(-0.2)\end{array}$ & & $\begin{array}{l}-0.0016 \\
(-0.4)\end{array}$ & $\begin{array}{l}-0.0499 \\
(-0.6)\end{array}$ & $\begin{array}{l}-0.0013 \\
(-0.2)\end{array}$ & $\begin{array}{l}0.0541 \\
(0.8)\end{array}$ \\
\hline KKS2 & $\begin{array}{l}0.0135 \\
(0.4)\end{array}$ & $\begin{array}{l}0.0133 \\
(0.6)\end{array}$ & $\begin{array}{l}-0.1008 \\
(-1.0)\end{array}$ & $\begin{array}{l}-0.0018 \\
(-0.2)\end{array}$ & $\begin{array}{l}0.0022 \\
(0.4)\end{array}$ & & $\begin{array}{l}-0.0482 \\
(-0.6)\end{array}$ & $\begin{array}{l}0.0003 \\
(-0.2)\end{array}$ & $\begin{array}{l}0.0557 \\
(0.8)\end{array}$ \\
\hline FGK & $\begin{array}{l}0.1001 \\
(1.0)\end{array}$ & $\begin{array}{l}0.0999 \\
(1.0)\end{array}$ & $\begin{array}{l}-0.0142 \\
(-0.4)\end{array}$ & $\begin{array}{l}0.0849 \\
(0.6)\end{array}$ & $\begin{array}{l}0.0888 \\
(0.8)\end{array}$ & $\begin{array}{l}0.0866 \\
(0.8)\end{array}$ & & $\begin{array}{l}0.0485 \\
(0.2)\end{array}$ & $\begin{array}{l}0.1039 \\
(1.0)\end{array}$ \\
\hline RP_ADJ & $\begin{array}{l}0.0256 \\
(0.8)\end{array}$ & $\begin{array}{l}0.0254 \\
(0.8)\end{array}$ & $\begin{array}{l}-0.0888 \\
(-1.0)\end{array}$ & $\begin{array}{l}0.0103 \\
(0.2)\end{array}$ & $\begin{array}{l}0.0143 \\
(0.2)\end{array}$ & $\begin{array}{l}0.0121 \\
(0.2)\end{array}$ & $\begin{array}{l}-0.0745 \\
(-1.0)\end{array}$ & & $\begin{array}{l}0.0554 \\
(0.6)\end{array}$ \\
\hline BV & $\begin{array}{l}-0.0111 \\
(-0.6)\end{array}$ & $\begin{array}{l}-0.0113 \\
(-0.6)\end{array}$ & $\begin{array}{l}-0.1254 \\
(-1.0)\end{array}$ & $\begin{array}{l}-0.0263 \\
(-0.6)\end{array}$ & $\begin{array}{l}-0.0224 \\
(-1.0)\end{array}$ & $\begin{array}{l}-0.0246 \\
(-1.0)\end{array}$ & $\begin{array}{l}-0.1112 \\
(-1.0)\end{array}$ & $\begin{array}{l}-0.0367 \\
(-1.0) \\
\text { intinued on }\end{array}$ & page) \\
\hline
\end{tabular}


TABLE 6 (continued)

Estimation Errors:

6-Month Horizon, Daily Data (Further Implied and DJIA)

\begin{tabular}{|c|c|c|c|c|c|c|c|c|c|c|}
\hline \multicolumn{11}{|c|}{ Panel B. DJIA } \\
\hline & HIST & RW & DCC & CCJV & SR & KKS1 & KKS2 & FGK & $\underline{\text { RP_ADJ }}$ & BV \\
\hline Avg. & 0.1569 & 0.1558 & 0.2356 & 0.2627 & 0.2434 & 0.1798 & 0.1730 & 0.2067 & 0.1965 & 0.1560 \\
\hline HIST & & $\begin{array}{l}0.0011 \\
(0.0)\end{array}$ & $\begin{array}{l}-0.0787 \\
(-1.0)\end{array}$ & $\begin{array}{l}-0.1058 \\
(-1.0)\end{array}$ & $\begin{array}{l}-0.0865 \\
(-0.5)\end{array}$ & $\begin{array}{l}-0.0229 \\
(-0.5)\end{array}$ & $\begin{array}{l}-0.0161 \\
(-0.5)\end{array}$ & $\begin{array}{l}-0.0498 \\
(-1.0)\end{array}$ & $\begin{array}{l}-0.0396 \\
(-0.5)\end{array}$ & $\begin{array}{l}0.0009 \\
(0.0)\end{array}$ \\
\hline RW & $\begin{array}{c}-0.0005 \\
(0.0)\end{array}$ & & $\begin{array}{l}-0.0798 \\
(-1.0)\end{array}$ & $\begin{array}{l}-0.1069 \\
(-0.5)\end{array}$ & $\begin{array}{l}-0.0876 \\
(-0.5)\end{array}$ & $\begin{array}{l}-0.0240 \\
(-0.5)\end{array}$ & $\begin{array}{l}-0.0173 \\
(-0.5)\end{array}$ & $\begin{array}{l}-0.0509 \\
(-1.0)\end{array}$ & $\begin{array}{l}-0.0407 \\
(-0.5)\end{array}$ & $\begin{array}{l}-0.0002 \\
(0.0)\end{array}$ \\
\hline DCC & $\begin{array}{l}0.0439 \\
(1.0)\end{array}$ & $\begin{array}{l}0.0444 \\
(1.0)\end{array}$ & & $\begin{array}{l}-0.0271 \\
(-0.5)\end{array}$ & $\begin{array}{l}-0.0078 \\
(0.0)\end{array}$ & $\begin{array}{l}0.0558 \\
(0.5)\end{array}$ & $\begin{array}{l}0.0626 \\
(0.5)\end{array}$ & $\begin{array}{l}0.0289 \\
(0.0)\end{array}$ & $\begin{array}{l}0.0391 \\
(0.0)\end{array}$ & $\begin{array}{l}0.0796 \\
(0.5)\end{array}$ \\
\hline CCJV & $\begin{array}{l}0.0821 \\
(1.0)\end{array}$ & $\begin{array}{l}0.0826 \\
(1.0)\end{array}$ & $\begin{array}{l}0.0382 \\
(0.5)\end{array}$ & & $\begin{array}{l}0.0193 \\
(0.0)\end{array}$ & $\begin{array}{l}0.0829 \\
(1.0)\end{array}$ & $\begin{array}{l}0.0897 \\
(1.0)\end{array}$ & $\begin{array}{l}0.0560 \\
(0.5)\end{array}$ & $\begin{array}{l}0.0662 \\
(0.5)\end{array}$ & $\begin{array}{l}0.1067 \\
(1.0)\end{array}$ \\
\hline SR & $\begin{array}{l}0.0784 \\
(0.5)\end{array}$ & $\begin{array}{l}0.0789 \\
(0.5)\end{array}$ & $\begin{array}{l}0.0344 \\
(0.0)\end{array}$ & $\begin{array}{l}-0.0037 \\
(-0.5)\end{array}$ & & $\begin{array}{l}0.0636 \\
(0.5)\end{array}$ & $\begin{array}{l}0.0704 \\
(0.5)\end{array}$ & $\begin{array}{l}0.0367 \\
(0.0)\end{array}$ & $\begin{array}{l}0.0469 \\
(0.5)\end{array}$ & $\begin{array}{l}0.0874 \\
(0.5)\end{array}$ \\
\hline KKS1 & $\begin{array}{l}0.0207 \\
(0.5)\end{array}$ & $\begin{array}{l}0.0212 \\
(0.5)\end{array}$ & $\begin{array}{l}-0.0232 \\
(-0.5)\end{array}$ & $\begin{array}{l}-0.0614 \\
(-1.0)\end{array}$ & $\begin{array}{l}-0.0577 \\
(-0.5)\end{array}$ & & $\begin{array}{l}0.0068 \\
(1.0)\end{array}$ & $\begin{array}{l}-0.0269 \\
(-0.5)\end{array}$ & $\begin{array}{c}-0.0167 \\
(0.0)\end{array}$ & $\begin{array}{l}0.0238 \\
(0.5)\end{array}$ \\
\hline KKS2 & $\begin{array}{l}0.0105 \\
(0.5)\end{array}$ & $\begin{array}{l}0.0110 \\
(0.5)\end{array}$ & $\begin{array}{l}-0.0334 \\
(-0.5)\end{array}$ & $\begin{array}{l}-0.0716 \\
(-1.0)\end{array}$ & $\begin{array}{l}-0.0679 \\
(-0.5)\end{array}$ & $\begin{array}{l}-0.0102 \\
(-1.0)\end{array}$ & & $\begin{array}{l}-0.0337 \\
(-0.5)\end{array}$ & $\begin{array}{l}-0.0235 \\
(-0.5)\end{array}$ & $\begin{array}{l}0.0170 \\
(0.5)\end{array}$ \\
\hline FGK & $\begin{array}{l}0.0650 \\
(1.0)\end{array}$ & $\begin{array}{l}0.0655 \\
(1.0)\end{array}$ & $\begin{array}{l}0.0211 \\
(0.0)\end{array}$ & $\begin{array}{l}-0.0171 \\
(0.0)\end{array}$ & $\begin{array}{l}-0.0134 \\
(0.0)\end{array}$ & $\begin{array}{l}0.0443 \\
(0.5)\end{array}$ & $\begin{array}{l}0.0545 \\
(0.5)\end{array}$ & & $\begin{array}{l}0.0102 \\
(0.0)\end{array}$ & $\begin{array}{l}0.0507 \\
(0.5)\end{array}$ \\
\hline RP_ADJ & $\begin{array}{l}0.0318 \\
(1.0)\end{array}$ & $\begin{array}{l}0.0323 \\
(1.0)\end{array}$ & $\begin{array}{l}-0.0122 \\
(-0.5)\end{array}$ & $\begin{array}{l}-0.0503 \\
(-0.5)\end{array}$ & $\begin{array}{l}-0.0466 \\
(0.0)\end{array}$ & $\begin{array}{l}0.0111 \\
(0.5)\end{array}$ & $\begin{array}{l}0.0213 \\
(0.5)\end{array}$ & $\begin{array}{l}-0.0332 \\
(-0.5)\end{array}$ & & $\begin{array}{l}0.0405 \\
(1.0)\end{array}$ \\
\hline BV & $\begin{array}{l}0.0093 \\
(0.5)\end{array}$ & $\begin{array}{l}0.0098 \\
(0.5)\end{array}$ & $\begin{array}{l}-0.0347 \\
(-1.0)\end{array}$ & $\begin{array}{l}-0.0728 \\
(-1.0)\end{array}$ & $\begin{array}{l}-0.0691 \\
(-0.5)\end{array}$ & $\begin{array}{l}-0.0114 \\
(-1.0)\end{array}$ & $\begin{array}{l}-0.0012 \\
(-0.5)\end{array}$ & $\begin{array}{l}-0.0557 \\
(-1.0)\end{array}$ & $\begin{array}{l}-0.0225 \\
(-1.0)\end{array}$ & \\
\hline
\end{tabular}

pared with CCJV. However, HIST, RW, and BV still yield even lower errors. To summarize, even the simple historical benchmark is to be preferred over all the fully implied methods taken into consideration. The assumptions that have to be made on (co-)moments for the fully implied estimators therefore seem to be invalid. BV, RW, and HIST, utilizing correlations from historical return data, consistently outperform these models.

\section{Option Liquidity}

Because option-implied approaches strongly rely on precise estimates for the option-implied moments, the rather poor performance could be caused by poor quality of the options data, resulting in imprecise moment estimates. To check for that, we repeat our analysis for all stocks contained in the DJIA $30 .{ }^{27}$ The DJIA includes 30 of the largest U.S. companies that both commonly have more options traded (in terms of strike prices) and exhibit a much higher liquidity compared with smaller stocks in the S\&P 500. ${ }^{28}$ Although Chakravarty, Gulen, and Mayhew (2004) find that option market price discovery is related to trading volume, considering only very liquid options may yield more precise estimates for the implied approaches.

The results are presented in Panel B of Table 6. We find that the fully implied approaches CCJV, SR, KKS1, and KKS2 still obtain larger errors in comparison

\footnotetext{
${ }^{27}$ Because some methods require information on all members of an index, it is not possible to just select a subset of stocks from the S\&P 500. Thus, we focus on an index that has significantly fewer members than the S\&P 500.

${ }^{28}$ Note that although the total turnover on S\&P 500 index options is substantially higher than that on DJIA index options, on average the daily total contract volume on DJIA index options of about 23,000 should be sufficiently high to obtain accurate moment estimates, even at the 6-month horizon.
} 
with HIST, RW, and BV. ${ }^{29}$ The results further show that HIST, RW, and BV obtain significantly smaller mean and median errors for at least one of the two portfolios. Thus, even when restricting the sample to the DJIA, the fully implied models are inferior to a simple historical estimate. The adjustment for the volatility risk premium (RP_ADJ), which also may be better fitted for better-quality options data, yields lower errors compared with FGK, whereas the differences are not statistically significant in most cases. Finally, under the presumably better options data, the average RMSE values of HIST, RW, and BV are approximately equal, with RW yielding the lowest average RMSE. The RMSE values of HIST, RW, and $\mathrm{BV}$ are significantly lower than those of the remaining approaches for at least one of the two portfolios.

\section{E. Further Time-Series Models}

We investigate further models imposing a time-varying structure on beta, namely, a random walk with drift, a first-order autoregressive (AR(1)) model, an autoregressive moving average ARMA $(1,1)$ model, and the CCC model of Bollerslev (1990), as well as realized beta over the past 6 months $\left(\mathrm{HIST}_{6}\right){ }^{30}$ Lewellen and Nagel (2006) argue that the results of short-term regressions provide conditional parameters without the use of conditioning variables as long as the parameters are relatively stable within that short period. Consequently, $\mathrm{HIST}_{6}$ might deliver better conditional estimates than the simple historical estimator using 1 year of historical return data.

In Table 7 we find $\mathrm{RW}_{\mathrm{D}}$, AR, ARMA, and especially $\mathrm{HIST}_{6}$ to perform quite well, whereas CCC is clearly outperformed. ${ }^{31}$ Furthermore, it can be seen that the less complex structure as in CCC yields a slight improvement when comparing the results to those of DCC. HIST $_{6}$ obtains a smaller average RMSE compared to the historical estimate over 1 year, so short-term conditional estimates may be better fitted. The average RMSE values of $\mathrm{RW}_{\mathrm{D}}$, AR, and ARMA are only moderate, but clearly higher than those of $\mathrm{BV}$, which overall again yields the lowest average RMSE. Regarding significance, we find that HIST, HIST 6 , RW, and BV yield significantly lower errors than AR, ARMA, DCC, and CCC for at least four portfolios. Only in rare cases are there significant differences among the formerly mentioned approaches, but in these cases, they are mostly in favor of BV. Overall we find, besides HIST and RW, HIST 6 to be a valuable alternative to the BV approach. ${ }^{32}$

\section{F. Bias Removal}

As we discuss in Section III.A, some estimators are heavily biased with their cross-sectional value-weighted average estimate for beta, a quantity that theoret-

\footnotetext{
${ }^{29}$ The results for the 1-month horizon, where both the options on the index and those on the individual assets should be more frequently traded, are qualitatively equal.

${ }^{30}$ Note that adding a drift in models (18) and (19) for AR and ARMA does especially affect ARMA adversely for long horizons. Consequently, we only report the results of the models without drift.

${ }^{31}$ Note that the values change slightly compared to those in Table 3 because we are able to retain more estimates when CCJV is not included in the analysis.

${ }^{32}$ The results for the 1-month horizon, where the conditional estimates of the time-series approaches are likely much more precise, are qualitatively equal. Overall, BV delivers a lower RMSE compared with all time-series approaches.
} 
ically has to be equal to 1 if a full market index is used, being substantially different from that value. A possible improvement could be to try to remove the bias implied by these deviations. ${ }^{33}$

A first simple method we try is to standardize the estimators in a way that their cross-sectional value-weighted average exactly equals 1 . For that, for each approach, we simply divide each estimate by the cross-sectional value-weighted mean beta of that approach at that time. We apply the technique on all estimators except those that fulfill the condition already by construction (e.g., KKS1 and BV). The results are shown in Panel A of Table 8. Indeed, the simple bias removal seems to be working, in particular for the two hybrid estimators FGK and RP_ADJ, reducing their RMSE values almost to the level of BV, with a significant difference for no portfolio, comparing BV to FGK. ${ }^{34}$ Consequently, the main benefit of the BV approach seems to be not the adjustment of correlations to the risk-neutral probability measure but rather to ensure that the estimates combining option-implied and historical return information are approximatively unbiased in their cross-sectional average. For CCJV and DCC, the bias removal yields a substantial improvement; however, these estimators are still inferior, whereas the improvement is quite small for HIST and RW.

\section{TABLE 7}

Estimation Errors: 6-Month Horizon, Daily Data (Further Time-Series Models)

\begin{tabular}{|c|c|c|c|c|c|c|c|c|c|}
\hline & HIST & $\mathrm{HIST}_{6}$ & $\mathrm{~W}$ & $\mathrm{RW}_{\mathrm{D}}$ & AR & ARMA & DCC & $\mathrm{CCC}$ & BV \\
\hline vg. & 0.1355 & 0.1283 & 0.1269 & 0.1870 & 0.1865 & 0.1899 & 0.2638 & 0.2572 & 0.1152 \\
\hline IIST & & $\begin{array}{l}0.0072 \\
(0.0)\end{array}$ & $\begin{array}{l}0.0086 \\
(0.0)\end{array}$ & $\begin{array}{l}-0.0515 \\
(-0.4)\end{array}$ & $\begin{array}{l}-0.0510 \\
(-0.8)\end{array}$ & $\begin{array}{l}-0.0543 \\
(-0.8)\end{array}$ & $\begin{array}{l}-0.1283 \\
(-1.0)\end{array}$ & $\begin{array}{l}-0.1217 \\
(-0.8)\end{array}$ & $\begin{array}{l}0.0203 \\
(0.2)\end{array}$ \\
\hline $\mathrm{HST}_{6}$ & $\begin{array}{l}-0.0041 \\
(-0.2)\end{array}$ & & $\begin{array}{l}0.0014 \\
(0.0)\end{array}$ & $\begin{array}{l}-0.0587 \\
(-1.0)\end{array}$ & $\begin{array}{l}-0.0582 \\
(-1.0)\end{array}$ & $\begin{array}{l}-0.0616 \\
(-1.0)\end{array}$ & $\begin{array}{l}-0.1356 \\
(-1.0)\end{array}$ & $\begin{array}{l}-0.1289 \\
(-0.8)\end{array}$ & $\begin{array}{l}0.0131 \\
(0.2)\end{array}$ \\
\hline WW & $\begin{array}{l}-0.0022 \\
(-0.2)\end{array}$ & $\begin{array}{l}0.0019 \\
(0.0)\end{array}$ & & $\begin{array}{l}-0.0601 \\
(-0.8)\end{array}$ & $\begin{array}{l}-0.0596 \\
(-1.0)\end{array}$ & $\begin{array}{l}-0.0630 \\
(-1.0)\end{array}$ & $\begin{array}{l}-0.1370 \\
(-1.0)\end{array}$ & $\begin{array}{l}-0.1303 \\
(-0.8)\end{array}$ & $\begin{array}{l}0.0117 \\
(0.2)\end{array}$ \\
\hline $2 W_{D}$ & $\begin{array}{l}0.0394 \\
(0.8)\end{array}$ & $\begin{array}{l}0.0435 \\
(1.0)\end{array}$ & $\begin{array}{l}0.0416 \\
(1.0)\end{array}$ & & $\begin{array}{l}0.0005 \\
(0.0)\end{array}$ & $\begin{array}{l}-0.0029 \\
(0.0)\end{array}$ & $\begin{array}{l}-0.0769 \\
(-0.8)\end{array}$ & $\begin{array}{c}-0.0702 \\
(0.0)\end{array}$ & $\begin{array}{l}0.0718 \\
(0.8)\end{array}$ \\
\hline $\mathrm{R}$ & $\begin{array}{l}0.0345 \\
(1.0)\end{array}$ & $\begin{array}{l}0.0385 \\
(1.0)\end{array}$ & $\begin{array}{l}0.0366 \\
(1.0)\end{array}$ & $\begin{array}{l}-0.0049 \\
(-0.2)\end{array}$ & & $\begin{array}{l}-0.0034 \\
(0.2)\end{array}$ & $\begin{array}{l}-0.0774 \\
(-0.8)\end{array}$ & $\begin{array}{c}-0.0707 \\
(0.0)\end{array}$ & $\begin{array}{l}0.0713 \\
(0.8)\end{array}$ \\
\hline RMA & $\begin{array}{l}0.0369 \\
(1.0)\end{array}$ & $\begin{array}{l}0.0410 \\
(1.0)\end{array}$ & $\begin{array}{l}0.0391 \\
(1.0)\end{array}$ & $\begin{array}{l}-0.0025 \\
(-0.2)\end{array}$ & $\begin{array}{l}0.0024 \\
(-0.2)\end{array}$ & & $\begin{array}{l}-0.0740 \\
(-0.8)\end{array}$ & $\begin{array}{l}-0.0673 \\
(-0.2)\end{array}$ & $\begin{array}{l}0.0746 \\
(0.8)\end{array}$ \\
\hline CCC & $\begin{array}{l}0.0638 \\
(1.0)\end{array}$ & $\begin{array}{l}0.0679 \\
(1.0)\end{array}$ & $\begin{array}{l}0.0660 \\
(1.0)\end{array}$ & $\begin{array}{l}0.0244 \\
(0.8)\end{array}$ & $\begin{array}{l}0.0293 \\
(0.8)\end{array}$ & $\begin{array}{l}0.0269 \\
(0.8)\end{array}$ & & $\begin{array}{l}0.0067 \\
(0.0)\end{array}$ & $\begin{array}{l}0.1486 \\
(1.0)\end{array}$ \\
\hline $\mathrm{CCC}$ & $\begin{array}{l}0.0338 \\
(1.0)\end{array}$ & $\begin{array}{l}0.0379 \\
(1.0)\end{array}$ & $\begin{array}{l}0.0360 \\
(1.0)\end{array}$ & $\begin{array}{l}-0.0055 \\
(0.0)\end{array}$ & $\begin{array}{c}-0.0006 \\
(0.0)\end{array}$ & $\begin{array}{c}-0.0031 \\
(0.2)\end{array}$ & $\begin{array}{l}-0.0299 \\
(-0.8)\end{array}$ & & $\begin{array}{l}0.1420 \\
(0.8)\end{array}$ \\
\hline $3 \mathrm{~V}$ & $\begin{array}{l}-0.0137 \\
(-0.8)\end{array}$ & $\begin{array}{l}-0.0096 \\
(-0.6)\end{array}$ & $\begin{array}{l}-0.0115 \\
(-0.6)\end{array}$ & $\begin{array}{l}-0.0531 \\
(-0.8)\end{array}$ & $\begin{array}{l}-0.0482 \\
(-1.0)\end{array}$ & $\begin{array}{l}-0.0506 \\
(-0.8)\end{array}$ & $\begin{array}{l}-0.0775 \\
(-1.0)\end{array}$ & $\begin{array}{l}-0.0475 \\
(-0.8)\end{array}$ & \\
\hline
\end{tabular}

\footnotetext{
${ }^{33} \mathrm{We}$ thank an anonymous referee for suggesting this.

${ }^{34}$ As can be seen in the Internet Appendix (available at www.jfqa.org), further analysis shows that BV still is informationally more efficient compared with the bias-removed FGK and RP_ADJ.
} 
We also employ more refined bias-removal techniques in the spirit of Mincer and Zarnowitz (1969) using regression techniques as in equation (28). ${ }^{35} \mathrm{In}$ a first approach we form portfolios as in Section III.B, obtain estimates for

\section{TABLE 8}

\section{Bias Removal}

Table 8 reports the out-of-sample estimation errors of competing bias-removed estimators, using daily return data, for realized beta over the horizon of 6 months for each portfolio. We build five quintile portfolios into which the stocks are allocated in an ascending order according to their historical beta in the sorting period (taking place directly before the estimation period for historical beta without overlap and with equal length). We determine portfolio betas and returns as value-weighted averages. Panel A presents the results on a simple bias removal, and Panels B and C present the results on bias removals using regression techniques. In each panel, the first row reports the average RMSE of the estimation models over the five portfolios. The lowest errors among all approaches are indicated by italic font. The remainder of the tables report the difference in estimation errors. The upper triangular matrix reports the differences in root mean squared estimation errors, averaged over the five portfolios. Similarly, the lower triangular matrix reports the average median difference of estimation errors. We compute the difference between the errors of the model [name in row] and those of the model [name in column]. The absolute numbers in parentheses indicate the percentage of portfolios for which the difference is significant (e.g., 0.4 indicates that the differences for two out of five portfolios are statistically significant). If the differences are significant for all five portfolios, the figure is printed in bold font. Significance is tested by the modified Diebold-Mariano and the Wilcoxon signed-rank tests for the upper and lower triangular matrices, respectively. The sign indicates the direction of the significant differences. BVUC refers to the noncorrected BV estimates.

Panel A. Simple Bias Removal

\begin{tabular}{|c|c|c|c|c|c|c|c|c|}
\hline & HIST & RW & DCC & FGK & CCJV & KKS1 & BV & RP_ADJ \\
\hline Avg. & 0.1304 & 0.1263 & 0.1820 & 0.1200 & 0.1633 & 0.1704 & 0.1164 & 0.1272 \\
\hline HIST & & $\begin{array}{l}0.0041 \\
(-0.2)\end{array}$ & $\begin{array}{l}-0.0516 \\
(-0.8)\end{array}$ & $\begin{array}{l}0.0104 \\
(0.4)\end{array}$ & $\begin{array}{l}-0.0329 \\
(-0.4)\end{array}$ & $\begin{array}{l}-0.0400 \\
(-0.4)\end{array}$ & $\begin{array}{l}0.0141 \\
(0.2)\end{array}$ & $\begin{array}{l}0.0032 \\
(0.0)\end{array}$ \\
\hline RW & $\begin{array}{c}-0.0029 \\
(0.0)\end{array}$ & & $\begin{array}{l}-0.0556 \\
(-1.0)\end{array}$ & $\begin{array}{l}0.0063 \\
(0.2)\end{array}$ & $\begin{array}{l}-0.0370 \\
(-0.4)\end{array}$ & $\begin{array}{l}-0.0441 \\
(-0.4)\end{array}$ & $\begin{array}{l}0.0100 \\
(0.2)\end{array}$ & $\begin{array}{c}-0.0009 \\
(0.2)\end{array}$ \\
\hline DCC & $\begin{array}{l}0.0169 \\
(1.0)\end{array}$ & $\begin{array}{l}0.0199 \\
(1.0)\end{array}$ & & $\begin{array}{l}0.0619 \\
(1.0)\end{array}$ & $\begin{array}{l}0.0187 \\
(0.0)\end{array}$ & $\begin{array}{l}0.0115 \\
(0.0)\end{array}$ & $\begin{array}{l}0.0656 \\
(0.8)\end{array}$ & $\begin{array}{l}0.0548 \\
(0.8)\end{array}$ \\
\hline FGK & $\begin{array}{l}-0.0135 \\
(-0.6)\end{array}$ & $\begin{array}{l}-0.0106 \\
(-0.4)\end{array}$ & $\begin{array}{l}-0.0305 \\
(-1.0)\end{array}$ & & $\begin{array}{l}-0.0433 \\
(-0.6)\end{array}$ & $\begin{array}{l}-0.0504 \\
(-0.4)\end{array}$ & $\begin{array}{l}0.0037 \\
(0.0)\end{array}$ & $\begin{array}{l}-0.0072 \\
(-0.4)\end{array}$ \\
\hline CCJV & $\begin{array}{l}0.0150 \\
(0.6)\end{array}$ & $\begin{array}{l}0.0180 \\
(0.6)\end{array}$ & $\begin{array}{l}-0.0019 \\
(-0.4)\end{array}$ & $\begin{array}{l}0.0285 \\
(1.0)\end{array}$ & & $\begin{array}{c}-0.0071 \\
(0.0)\end{array}$ & $\begin{array}{l}0.0470 \\
(0.8)\end{array}$ & $\begin{array}{l}0.0361 \\
(0.4)\end{array}$ \\
\hline KKS1 & $\begin{array}{l}0.0092 \\
(0.4)\end{array}$ & $\begin{array}{l}0.0122 \\
(0.4)\end{array}$ & $\begin{array}{l}-0.0077 \\
(-0.4)\end{array}$ & $\begin{array}{l}0.0227 \\
(0.6)\end{array}$ & $\begin{array}{l}-0.0058 \\
(-0.2)\end{array}$ & & $\begin{array}{l}0.0541 \\
(0.8)\end{array}$ & $\begin{array}{l}0.0432 \\
(0.4)\end{array}$ \\
\hline BV & $\begin{array}{l}-0.0132 \\
(-0.6)\end{array}$ & $\begin{array}{l}-0.0102 \\
(-0.6)\end{array}$ & $\begin{array}{l}-0.0301 \\
(-0.8)\end{array}$ & $\begin{array}{l}0.0004 \\
(0.0)\end{array}$ & $\begin{array}{l}-0.0282 \\
(-1.0)\end{array}$ & $\begin{array}{l}-0.0224 \\
(-1.0)\end{array}$ & & $\begin{array}{c}-0.0108 \\
(0.0)\end{array}$ \\
\hline RP_ADJ & $\begin{array}{l}-0.0093 \\
(-0.2)\end{array}$ & $\begin{array}{l}-0.0064 \\
(-0.4)\end{array}$ & $\begin{array}{l}-0.0263 \\
(-1.0)\end{array}$ & $\begin{array}{l}0.0042 \\
(0.0)\end{array}$ & $\begin{array}{l}-0.0243 \\
(-0.8)\end{array}$ & $\begin{array}{l}-0.0185 \\
(-0.6)\end{array}$ & $\begin{array}{l}0.0038 \\
(0.6)\end{array}$ & \\
\hline
\end{tabular}

Panel B. Regression Technique

\begin{tabular}{|c|c|c|c|c|c|c|c|c|c|}
\hline & HIST & $\mathrm{RW}$ & DCC & FGK & CCJV & KKS1 & $\mathrm{BV}$ & $\underline{R P \_A D J}$ & $\mathrm{BV}^{\mathrm{UC}}$ \\
\hline Avg. & 0.1941 & 0.1630 & 0.2595 & 0.1976 & 0.2461 & 0.1601 & 0.1286 & 0.2066 & 0.1203 \\
\hline HIST & & $\begin{array}{l}0.0311 \\
(0.0)\end{array}$ & $\begin{array}{l}-0.0654 \\
(-0.6)\end{array}$ & $\begin{array}{l}-0.0035 \\
(-0.4)\end{array}$ & $\begin{array}{l}-0.0520 \\
(-0.4)\end{array}$ & $\begin{array}{l}0.0340 \\
(0.0)\end{array}$ & $\begin{array}{l}0.0655 \\
(0.4)\end{array}$ & $\begin{array}{l}-0.0125 \\
(-0.4)\end{array}$ & $\begin{array}{l}0.0738 \\
(0.4)\end{array}$ \\
\hline RW & $\begin{array}{l}-0.0142 \\
(-0.6)\end{array}$ & & $\begin{array}{l}-0.0965 \\
(-1.0)\end{array}$ & $\begin{array}{l}-0.0346 \\
(-0.8)\end{array}$ & $\begin{array}{l}-0.0831 \\
(-0.4)\end{array}$ & $\begin{array}{l}0.0029 \\
(0.0)\end{array}$ & $\begin{array}{l}0.0345 \\
(0.2)\end{array}$ & $\begin{array}{l}-0.0436 \\
(-0.6)\end{array}$ & $\begin{array}{l}0.0427 \\
(0.2)\end{array}$ \\
\hline DCC & $\begin{array}{l}0.0516 \\
(0.8)\end{array}$ & $\begin{array}{l}0.0657 \\
(1.0)\end{array}$ & & $\begin{array}{l}0.0619 \\
(0.6)\end{array}$ & $\begin{array}{l}0.0134 \\
(0.0)\end{array}$ & $\begin{array}{l}0.0994 \\
(0.8)\end{array}$ & $\begin{array}{l}0.1310 \\
(1.0)\end{array}$ & $\begin{array}{l}0.0529 \\
(0.4)\end{array}$ & $\begin{array}{l}0.1392 \\
(1.0)\end{array}$ \\
\hline FGK & $\begin{array}{l}0.0207 \\
(0.6)\end{array}$ & $\begin{array}{l}0.0349 \\
(0.8)\end{array}$ & $\begin{array}{l}-0.0309 \\
(-0.6)\end{array}$ & & $\begin{array}{l}-0.0486 \\
(-0.2)\end{array}$ & $\begin{array}{l}0.0374 \\
(0.8)\end{array}$ & $\begin{array}{l}0.0690 \\
(0.8)\end{array}$ & $\begin{array}{l}-0.0091 \\
(0.0)\end{array}$ & $\begin{array}{l}0.0773 \\
(0.8)\end{array}$ \\
\hline CCJV & $\begin{array}{l}0.0320 \\
(0.4)\end{array}$ & $\begin{array}{l}0.0462 \\
(1.0)\end{array}$ & $\begin{array}{l}-0.0195 \\
(-0.4)\end{array}$ & $\begin{array}{l}0.0113 \\
(0.4)\end{array}$ & & $\begin{array}{l}0.0860 \\
(0.6)\end{array}$ & $\begin{array}{l}0.1176 \\
(0.6)\end{array}$ & $\begin{array}{l}0.0395 \\
(0.2)\end{array}$ & $\begin{array}{l}0.1258 \\
(0.6)\end{array}$ \\
\hline KKS1 & $\begin{array}{l}-0.0148 \\
(-0.6)\end{array}$ & $\begin{array}{l}-0.0006 \\
(-0.2)\end{array}$ & $\begin{array}{l}-0.0663 \\
(-1.0)\end{array}$ & $\begin{array}{l}-0.0354 \\
(-0.6)\end{array}$ & $\begin{array}{l}-0.0468 \\
(-1.0)\end{array}$ & & $\begin{array}{l}0.0316 \\
(0.0)\end{array}$ & $\begin{array}{l}-0.0465 \\
(-0.8)\end{array}$ & $\begin{array}{l}0.0398 \\
(0.4)\end{array}$ \\
\hline BV & $\begin{array}{l}-0.0199 \\
(-1.0)\end{array}$ & $\begin{array}{l}-0.0057 \\
(-0.4)\end{array}$ & $\begin{array}{l}-0.0715 \\
(-1.0)\end{array}$ & $\begin{array}{l}-0.0406 \\
(-0.8)\end{array}$ & $\begin{array}{l}-0.0519 \\
(-1.0)\end{array}$ & $\begin{array}{l}-0.0051 \\
(-0.2)\end{array}$ & & $\begin{array}{l}-0.0781 \\
(-0.8)\end{array}$ & $\begin{array}{l}0.0082 \\
(0.0)\end{array}$ \\
\hline RP_ADJ & $\begin{array}{l}0.0201 \\
(0.6)\end{array}$ & $\begin{array}{l}0.0342 \\
(0.8)\end{array}$ & $\begin{array}{l}-0.0315 \\
(-0.6)\end{array}$ & $\begin{array}{c}-0.0006 \\
(0.0)\end{array}$ & $\begin{array}{l}-0.0120 \\
(-0.6)\end{array}$ & $\begin{array}{l}0.0348 \\
(0.8)\end{array}$ & $\begin{array}{l}0.0399 \\
(1.0)\end{array}$ & & $\begin{array}{l}0.0863 \\
(0.8)\end{array}$ \\
\hline$B V^{U C}$ & $\begin{array}{l}-0.0317 \\
(-1.0)\end{array}$ & $\begin{array}{l}-0.0175 \\
(-0.8)\end{array}$ & $\begin{array}{l}-0.0833 \\
(-1.0)\end{array}$ & $\begin{array}{l}-0.0524 \\
(-1.0)\end{array}$ & $\begin{array}{l}-0.0637 \\
(-1.0)\end{array}$ & $\begin{array}{l}-0.0169 \\
(-1.0)\end{array}$ & $\begin{array}{l}-0.0118 \\
(-0.4)\end{array}$ & $\begin{array}{l}-0.0517 \\
(-1.0)\end{array}$ & \\
\hline
\end{tabular}

(continued on next page)

${ }^{35}$ We consider further possibilities to try to remove bias in the Internet Appendix (available at www.jfqa.org). 
Bias Removal

Panel C. Regression Technique Combining with HIST

\begin{tabular}{|c|c|c|c|c|c|c|c|c|c|}
\hline & HIST & $\mathrm{RW}$ & DCC & FGK & CCJV & KKS1 & BV & $\underline{\text { RP_ADJ }}$ & BVuc \\
\hline Avg. & 0.1941 & 0.1879 & 0.1998 & 0.1898 & 0.1765 & 0.1716 & 0.1367 & 0.1894 & 0.1203 \\
\hline HIST & & $\begin{array}{l}0.0062 \\
(0.0)\end{array}$ & $\begin{array}{c}-0.0057 \\
(0.0)\end{array}$ & $\begin{array}{c}0.0043 \\
(-0.2)\end{array}$ & $\begin{array}{l}0.0176 \\
(0.0)\end{array}$ & $\begin{array}{l}0.0224 \\
(0.0)\end{array}$ & $\begin{array}{l}0.0574 \\
(0.4)\end{array}$ & $\begin{array}{l}0.0047 \\
(0.0)\end{array}$ & $\begin{array}{l}0.0738 \\
(0.4)\end{array}$ \\
\hline RW & $\begin{array}{l}-0.0061 \\
(-0.2)\end{array}$ & & $\begin{array}{c}-0.0119 \\
(0.0)\end{array}$ & $\begin{array}{c}-0.0019 \\
(0.0)\end{array}$ & $\begin{array}{l}0.0114 \\
(0.0)\end{array}$ & $\begin{array}{l}0.0162 \\
(0.2)\end{array}$ & $\begin{array}{l}0.0512 \\
(0.2)\end{array}$ & $\begin{array}{c}-0.0015 \\
(0.0)\end{array}$ & $\begin{array}{l}0.0676 \\
(0.6)\end{array}$ \\
\hline DCC & $\begin{array}{l}0.0044 \\
(0.2)\end{array}$ & $\begin{array}{l}0.0104 \\
(0.4)\end{array}$ & & $\begin{array}{l}0.0099 \\
(0.0)\end{array}$ & $\begin{array}{l}0.0232 \\
(0.0)\end{array}$ & $\begin{array}{l}0.0281 \\
(0.4)\end{array}$ & $\begin{array}{l}0.0630 \\
(0.6)\end{array}$ & $\begin{array}{l}0.0104 \\
(0.0)\end{array}$ & $\begin{array}{l}0.0794 \\
(0.6)\end{array}$ \\
\hline FGK & $\begin{array}{l}-0.0011 \\
(0.0)\end{array}$ & $\begin{array}{l}0.0050 \\
(0.2)\end{array}$ & $\begin{array}{l}-0.0054 \\
(-0.2)\end{array}$ & & $\begin{array}{l}0.0133 \\
(0.0)\end{array}$ & $\begin{array}{l}0.0182 \\
(0.6)\end{array}$ & $\begin{array}{l}0.0531 \\
(0.4)\end{array}$ & $\begin{array}{l}0.0004 \\
(0.0)\end{array}$ & $\begin{array}{l}0.0695 \\
(0.6)\end{array}$ \\
\hline CCJ & $\begin{array}{l}0.0016 \\
(0.0)\end{array}$ & $\begin{array}{l}0.0077 \\
(0.0)\end{array}$ & $\begin{array}{l}-0.0027 \\
(-0.4)\end{array}$ & $\begin{array}{l}0.0027 \\
(-0.2)\end{array}$ & & $\begin{array}{l}0.0049 \\
(0.0)\end{array}$ & $\begin{array}{l}0.0398 \\
(0.4)\end{array}$ & $\begin{array}{l}-0.0129 \\
(0.0)\end{array}$ & $\begin{array}{l}0.0562 \\
(0.8)\end{array}$ \\
\hline KKS & $\begin{array}{l}-0.0116 \\
(-0.8)\end{array}$ & $\begin{array}{l}-0.0055 \\
(-0.4)\end{array}$ & $\begin{array}{l}-0.0160 \\
(-0.8)\end{array}$ & $\begin{array}{l}-0.0105 \\
(-0.8)\end{array}$ & $\begin{array}{l}-0.0133 \\
(-0.2)\end{array}$ & & $\begin{array}{l}0.0349 \\
(0.0)\end{array}$ & $\begin{array}{l}-0.0178 \\
(-0.4)\end{array}$ & $\begin{array}{l}0.0513 \\
(0.2)\end{array}$ \\
\hline BV & $\begin{array}{l}-0.0202 \\
(-1.0)\end{array}$ & $\begin{array}{l}-0.0141 \\
(-1.0)\end{array}$ & $\begin{array}{l}-0.0246 \\
(-1.0)\end{array}$ & $\begin{array}{l}-0.0192 \\
(-1.0)\end{array}$ & $\begin{array}{l}-0.0219 \\
(-1.0)\end{array}$ & $\begin{array}{l}-0.0086 \\
(-1.0)\end{array}$ & & $\begin{array}{l}-0.0527 \\
(-0.2)\end{array}$ & $\begin{array}{l}0.0164 \\
(0.0)\end{array}$ \\
\hline RP_AD & $\begin{array}{c}-0.0019 \\
(0.0)\end{array}$ & $\begin{array}{l}0.0042 \\
(0.4)\end{array}$ & $\begin{array}{l}-0.0062 \\
(-0.2)\end{array}$ & $\begin{array}{c}-0.0008 \\
(0.0)\end{array}$ & $\begin{array}{l}-0.0035 \\
(-0.2)\end{array}$ & $\begin{array}{l}0.0098 \\
(0.8)\end{array}$ & $\begin{array}{l}0.0184 \\
(1.0)\end{array}$ & & $\begin{array}{l}0.0691 \\
(0.6)\end{array}$ \\
\hline $\mathrm{BV}^{\mathrm{UC}}$ & $\begin{array}{l}-0.0317 \\
(-1.0)\end{array}$ & $\begin{array}{l}-0.0256 \\
(-1.0)\end{array}$ & $\begin{array}{l}-0.0360 \\
(-1.0)\end{array}$ & $\begin{array}{l}-0.0306 \\
(-1.0)\end{array}$ & $\begin{array}{l}-0.0333 \\
(-1.0)\end{array}$ & $\begin{array}{l}-0.0201 \\
(-0.8)\end{array}$ & $\begin{array}{l}-0.0115 \\
(-0.2)\end{array}$ & $\begin{array}{l}-0.0298 \\
(-1.0)\end{array}$ & \\
\hline
\end{tabular}

each approach, and then perform the univariate regression for each approach separately, pooling all 60 (12 months times 5 portfolios) unadjusted ex ante estimates for each approach $i$ as well as the corresponding ex post realized portfolio beta estimates during the 12 months $t-17$ up to $t-6$ (because realized beta with a 6 -month window is available only up to $t-6$ at time $t$ ):

$$
\beta^{\mathrm{R}}=a_{i, t}+b_{i, t} \beta_{i}^{\mathrm{UNADJ}}+\epsilon_{j},
$$

where $\beta_{i}^{\text {UNADJ }}$ is the vector of pooled initial portfolio beta estimates of one approach, and $\beta^{R}$ denotes the corresponding pooled realized beta vector. Subsequently, after obtaining the regression coefficients $\hat{a}_{i, t}$ and $\hat{b}_{i, t}$, we manipulate the current estimates, inserting them into the equation

$$
\beta_{i, j, t}^{\mathrm{ADJ}}=\hat{a}_{i, t}+\hat{b}_{i, t} \beta_{i, j, t}^{\mathrm{UNADJ}},
$$

where $\beta_{i, j, t}^{\mathrm{ADJ}}$ is the adjusted estimate of approach $i$ and asset $j$ at time $t$.

A second approach could be to try to remove the bias in the same spirit, combining it with the estimate for historical beta (HIST). For that, we perform a bivariate regression of portfolio realized beta on each approach and HIST over the 12 months $t-17$ up to $t-6$. The final adjustment is then performed as follows:

$$
\beta_{i, j, t}^{\mathrm{ADJ}}=\hat{a}_{i, t}+\hat{b}_{i, t}^{\beta} \beta_{i, j, t}^{\mathrm{UNADJ}}+\hat{b}_{i, t}^{\mathrm{HIST}} \mathrm{HIST}_{j, t},
$$

where $\mathrm{HIST}_{j, t}$ is the estimate for historical beta at time $t$, and $\hat{b}_{i, t}^{\beta}$ and $\hat{b}_{i, t}^{\mathrm{HIT}}$ are the regression coefficients on the considered approach and HIST, respectively. The results for these approaches are presented in Panels B and C of Table $8 .^{36}$

\footnotetext{
${ }^{36}$ Note that the results for the uncorrected $\mathrm{BV}^{\mathrm{UC}}$ differ from those in previous tables because the bias correction first needs 17 months of data before it starts, delaying the start of the evaluation period.
} 
The results for the adjustment of equation (31) indicate an even slightly higher average RMSE for BV, whereas all other approaches also yield (in many cases significantly) higher RMSE values than the initial BV. The adjustment of equation (32), combining the estimates with HIST, yields an improvement for DCC and the implied estimators FGK, CCJV, and RP_ADJ, indicating that not all information on historical returns is incorporated in these estimators. For all remaining approaches, including BV, the combination with HIST yields a higher RMSE compared with the simpler bias removal using equation (31).

Consequently, a simple bias removal is shown to be valuable in particular for hybrid estimators. Furthermore, our results suggest that a regression-based bias removal cannot further improve the performance of BV, HIST, and RW.

\section{Conclusion}

This paper examines the performance of a wide range of approaches to estimating an asset's market beta. Specifically, we investigate several constant and time-varying models relying on historical return data and additionally several methods including or solely relying on option-implied information.

In summary, estimators using historical information perform well only if they do not make too strong structural assumptions, like the simple historical beta and the Kalman filter approach with a random walk parametrization. In contrast, models that make strong assumptions on the volatility and correlation processes (like the GARCH-based DCC) are shown to produce very large errors.

Including information from option prices is shown to be valuable to some extent. Fully implied methods, having the big advantage of employing the forward-looking information from options markets, nonetheless adhere the major shortcoming that they cannot attain negative values. Consequently, even the models that are on average unbiased by construction (KKS1 and KKS2) produce substantial errors. Avoiding strong and seemingly invalid identifying assumptions, the hybrid approaches, combining historical return data with forward-looking information from the options market, are shown to produce the lowest errors. In particular, the hybrid approach of Buss and Vilkov (2012) consistently performs best regarding informational efficiency as well as estimation accuracy. These results are shown to be robust both to building more portfolios and different estimation horizons. Furthermore, we find that the main benefit of BV, compared with other hybrid approaches, is that it ensures that the estimates are adjusted to be unbiased in their value-weighted cross-sectional averages.

Overall, although the BV approach appears to be the method of choice, one major shortcoming of this method (and other hybrid approaches that try a simple bias correction) has to be borne in mind: the methodology requires information on a full market index. Consequently, it cannot be employed for assets that are not included in an index, or in cases where there is insufficient option-implied information for all assets in the index. Therefore, whenever the BV approach is not applicable, our results indicate that one should rely either on RW or a simple estimate based on historical returns, because both quite consistently outperform all other approaches. 


\section{References}

Agnolucci, P. "Volatility in Crude Oil Futures: A Comparison of the Predictive Ability of GARCH and Implied Volatility Models." Energy Economics, 31 (2009), 316-321.

Andersen, T. G.; T. Bollerslev; F. X. Diebold; and G. Wu. "Realized Beta: Persistence and Predictability." Advances in Econometrics, 20 (2006), 1-39.

Baker, M.; B. Bradley; and J. Wurgler. "Benchmarks as Limits to Arbitrage: Understanding the Low Volatility Anomaly." Financial Analysts Journal, 67 (2010), 40-54.

Bakshi, G.; N. Kapadia; and D. Madan. "Stock Return Characteristics, Skew Laws, and the Differential Pricing of Individual Equity Options." Review of Financial Studies, 16 (2003), 101-143.

Bakshi, G., and D. Madan. "Spanning and Derivative-Security Valuation." Journal of Financial Economics, 55 (2000), 205-238.

Bali, T. G.; R. F. Engle; and Y. Tang. "Dynamic Conditional Beta Is Alive and Well in the CrossSection of Daily Stock Returns.” Working Paper, Georgetown University (2015).

Baule, R.; O. Korn; and S. Saßning. "Which Beta Is Best? On the Information Content of OptionImplied Betas." European Financial Management, 22 (2016), 450-483.

Black, A.; P. Fraser; and D. Power. "UK Unit Trust Performance 1980-1989: A Passive Time-Varying Approach." Journal of Banking \& Finance, 16 (1992), 1015-1033.

Black, F. "Studies of Stock Price Volatility Changes." Proceedings of the 1976 Meetings of the American Statistical Association, Business and Economical Statistics Section, 34 (1976), 177-181.

Black, F., and M. Scholes. "The Pricing of Options and Corporate Liabilities." Journal of Political Economy, 81 (1973), 637-654.

Blume, M. E. "Betas and Their Regression Tendencies." Journal of Finance, 30 (1975), 785-795.

Bollerslev, T. "Modelling the Coherence in Short-Run Nominal Exchange Rates: A Multivariate Generalized ARCH Model." Review of Economics and Statistics, 72 (1990), 498-505.

Buss, A., and G. Vilkov. "Measuring Equity Risk with Option-Implied Correlations." Review of Financial Studies, 25 (2012), 3113-3140.

Canina, L., and S. Figlewski. "The Informational Content of Implied Volatility." Review of Financial Studies, 6 (1993), 659-681.

Cappiello, L.; R. F. Engle; and K. Sheppard. "Asymmetric Dynamics in the Correlations of Global Equity and Bond Returns." Journal of Financial Econometrics, 4 (2006), 537-572.

Carr, P., and L. Wu. "Variance Risk Premiums." Review of Financial Studies, 22 (2009), 1311-1341.

Chakravarty, S.; H. Gulen; and S. Mayhew. "Informed Trading in Stock and Option Markets." Journal of Finance, 59 (2004), 1235-1258.

Chang, B.-Y.; P. Christoffersen; K. Jacobs; and G. Vainberg. "Option-Implied Measures of Equity Risk." Review of Finance, 16 (2012), 385-428.

Charoenwong, C.; N. Jenwittayaroje; and B. S. Low. "Who Knows More about Future Currency Volatility?" Journal of Futures Markets, 29 (2009), 270-295.

Christensen, B. J., and N. R. Prabhala. "The Relation between Implied and Realized Volatility." Journal of Financial Economics, 50 (1998), 125-150.

Christie, A. A. "The Stochastic Behavior of Common Stock Variances: Value, Leverage and Interest Rate Effects." Journal of Financial Economics, 10 (1982), 407-432.

Dennis, P., and S. Mayhew. "Risk-Neutral Skewness: Evidence from Stock Options." Journal of Financial and Quantitative Analysis, 37 (2002), 471-493.

Driessen, J.; P. J. Maenhout; and G. Vilkov. "The Price of Correlation Risk: Evidence from Equity Options." Journal of Finance, 64 (2009), 1377-1406.

Engle, R. F. "Dynamic Conditional Correlation: A Simple Class of Multivariate Generalized Autoregressive Conditional Heteroskedasticity Models." Journal of Business \& Economic Statistics, 20 (2002), 339-350.

Engle, R. F. “Dynamic Conditional Beta.” Working Paper, New York University (2014).

Faff, R. W.; D. Hillier; and J. Hillier. "Time Varying Beta Risk: An Analysis of Alternative Modelling Techniques." Journal of Business Finance \& Accounting, 27 (2000), 523-554.

Fama, E. F., and J. D. MacBeth. "Risk, Return, and Equilibrium: Empirical Tests." Journal of Political Economy, 81 (1973), 607-636.

Ferson, W. E., and C. R. Harvey. "The Variation of Economic Risk Premiums." Journal of Political Economy, 99 (1991), 385-415.

Ferson, W. E., and C. R. Harvey. "The Risk and Predictability of International Equity Returns." Review of Financial Studies, 6 (1993), 527-566.

Fleming, J. "The Quality of Market Volatility Forecasts Implied by S\&P 100 Index Option Prices." Journal of Empirical Finance, 5 (1998), 317-345.

French, D. W.; J. C. Groth; and J. W. Kolari. "Current Investor Expectations and Better Betas.” Journal of Portfolio Management, 10 (1983), 12-17. 
Frijns, B.; C. Tallau; and A. Tourani-Rad. "The Information Content of Implied Volatility: Evidence from Australia." Journal of Futures Markets, 30 (2010), 134-155.

Ghysels, E. "On Stable Factor Structures in the Pricing of Risk: Do Time-Varying Betas Help or Hurt?" Journal of Finance, 53 (1998), 549-573.

Glosten, L. R.; R. Jagannathan; and D. E. Runkle. "On the Relation between the Expected Value and the Volatility of the Nominal Excess Return on Stocks." Journal of Finance, 48 (1993), 1779-1801.

Guo, D. "The Predictive Power of Implied Stochastic Variance from Currency Options." Journal of Futures Markets, 16 (1996), 915-942.

Hansen, P. R., and A. Lunde. "Consistent Ranking of Volatility Models." Journal of Econometrics, 131 (2006), 97-121.

Harvey, D.; S. Leybourne; and P. Newbold. "Testing the Equality of Prediction Mean Squared Errors." International Journal of Forecasting, 13 (1997), 281-291.

Jiang, G. J., and Y. S. Tian. "The Model-Free Implied Volatility and Its Information Content." Review of Financial Studies, 18 (2005), 1305-1342.

Jorion, P. "Predicting Volatility in the Foreign Exchange Market." Journal of Finance, 50 (1995), 507-528.

Kempf, A.; O. Korn; and S. Saßning. "Portfolio Optimization Using Forward-Looking Information." Review of Finance, 20 (2015), 467-490.

Lewellen, J., and S. Nagel. "The Conditional CAPM Does Not Explain Asset-Pricing Anomalies." Journal of Financial Economics, 82 (2006), 289-314.

Lintner, J. "The Valuation of Risk Assets and the Selection of Risky Investments in Stock Portfolios and Capital Budgets." Review of Economics and Statistics, 47 (1965), 13-37.

Martens, M., and J. Zein. "Predicting Financial Volatility: High-Frequency Time-Series Forecasts vis-à-vis Implied Volatility." Journal of Futures Markets, 24 (2004), 1005-1028.

Mincer, J. A., and V. Zarnowitz. "The Evaluation of Economic Forecasts." In Economic Forecasts and Expectations: Analysis of Forecasting Behavior and Performance, NBER (1969), 1-46.

Mossin, J. "Equilibrium in a Capital Asset Market.” Econometrica, 34 (1966), 768-783.

Newey, W. K., and K. D. West. "A Simple, Positive Semi-Definite, Heteroskedasticity and Autocorrelation Consistent Covariance Matrix.” Econometrica, 55 (1987), 703-708.

Pagan, A. "Some Identification and Estimation Results for Regression Models with Stochastically Varying Coefficients." Journal of Econometrics, 13 (1980), 341-363.

Pagan, A. R., and G. W. Schwert. "Alternative Models for Conditional Stock Volatility." Journal of Econometrics, 45 (1990), 267-290.

Patton, A. J. "Volatility Forecast Comparison Using Imperfect Volatility Proxies." Journal of Econometrics, 160 (2011), 246-256.

Poon, S.-H., and C. W. Granger. "Forecasting Volatility in Financial Markets: A Review." Journal of Economic Literature, 41 (2003), 478-539.

Prokopczuk, M., and C. Wese Simen. "The Importance of the Volatility Risk Premium for Volatility Forecasting." Journal of Banking \& Finance, 40 (2014), 303-320.

Ross, S. A. "The Arbitrage Theory of Capital Asset Pricing." Journal of Economic Theory, 13 (1976), 341-360.

Sharpe, W. F. "Capital Asset Prices: A Theory of Market Equilibrium under Conditions of Risk." Journal of Finance, 19 (1964), 425-442.

Siegel, A. F. "Measuring Systematic Risk Using Implicit Beta." Management Science, 41 (1995), 124-128.

Skintzi, V. D., and A.-P. N. Refenes. "Implied Correlation Index: A New Measure of Diversification." Journal of Futures Markets, 25 (2005), 171-197.

Szakmary, A.; E. Ors; J. K. Kim; and W. N. Davidson III. "The Predictive Power of Implied Volatility: Evidence from 35 Futures Markets.” Journal of Banking \& Finance, 27 (2003), 2151-2175.

Taylor, S. J.; P. K. Yadav; and Y. Zhang. "The Information Content of Implied Volatilities and ModelFree Volatility Expectations: Evidence from Options Written on Individual Stocks." Journal of Banking \& Finance, 34 (2010), 871-881. 